\title{
NAJSTARSZE (XI-XII W.) FIGURY SZACHOWE WYKONANE W STYLISTYCE ABSTRAKCYJNEJ ARABSKIEJ Z TERENU POLSKI, NA TLE TRENDÓW EUROPEJSKICH ZWIĄZANYCH Z POCZĄTKOWYMI FAZAMI ADAPTACJI W EUROPIE
}

\author{
THE OLDEST $\left(11^{\mathrm{TH}}-13^{\mathrm{TH}}\right.$ C. $)$ CHESS FIGURES MADE IN THE ABSTRACT \\ ARAB STYLE EXCAVATED IN POLAND AGAINST THE EUROPEAN \\ TRENDS RELATED TO THE INITIAL STAGES OF ADAPTATION \\ IN EUROPE
}

\begin{abstract}
Chess is a board game, in the Middle Ages referred to as a tabula. During the long way it took since its origin in India in the $6^{\text {th }}$ century until modern times, the subsequent communities left their own, inimitable cultural marks. In India, chess had a deeply mystical nature; Persians used chess to picture the world as a battlefield; Arabs systematised many concepts and took note of the mathematical aspect; Europe made use of chess to define rules that should apply to an ideal society. This shows a perfect understanding of the balance on the chessboard, the mutual dependencies and consistent actions leading to success - both when playing and creating social life. Medieval literature provides an excellent basis for studies of the intertwining cultural trends and describing the reality. In the literature, elements based on playing chess are oftentimes among the postulated modes of education. However, the ideas encountered by the potential users of chess tournaments were best communicated by the figures and the accumulated plethora of notions. An analysis of the changes affecting jackstraws at an early stage of the game's adaptation in Europe and other territories which took over chess as cultural models, leads to a conclusion that the material from the $11^{\text {th }}-12^{\text {th }}$ centuries that comes from Polish collections matches many Latin trends and shows considerable knowledge thereof.
\end{abstract}

Key words: chess, early Middle Ages, chess figures, Muslim abstract style.

* ORCID: 0000-0001-8492-4507, Muzeum Archeologiczne w Poznaniu - Rezerwat Archeologiczny Genius loci, ul. Ks. I. Posadzego 3, 61-108 Poznań, e-mail: agnieszka.stempin@muzarp.poznan.pl. 


\section{KWESTIE TERMINOLOGII I ROZRÓŻNIANIA FORM GIER}

Szachy należą do rodziny gier tablicowych, określanych w średniowieczu terminem tabula. Większość z nich, u zarania swojej historii, polegała na swoistym zapisie typów interakcji pomiędzy ludźmi należącymi do grupy, w której się wykształciły. Wypracowane reguły pozwalały na powtarzanie i ćwiczenie przyjętych tam zasad współżycia i postępowania, ich naukę, a także trening różnych strategii czy obserwowanie zależności oraz konsekwencji podejmowanych działań. To z kolei determinowało budowanie silnej więzi tożsamościowej pomiędzy osobami praktykującymi takie aktywności. W tym ujęciu gry najczęściej związane były z mitem założycielskim wyróżniającym daną społeczność (Banaszkiewicz 1999, s. 23-31; Bubczyk 2009, s. 70). Angażowały bóstwa i zdradzały ich stosunek do grających ludzi - poprzez element losowy (rzuty kośćmi) stanowiły płaszczyznę komunikacji ze sferą sacrum. Tak więc najbardziej podstawowy podział gier, jaki można zaproponować, biorąc pod uwagę przydatność ich jako materiału badawczego dla nauk historycznych, będzie polegał na rozróżnieniu tych, które zachowały charakter tożsamościowy konkretnej grupy, w przeciwieństwie do innych, które uległy (z różnych przyczyn) upowszechnieniu. Pierwsze to formy, które z założenia nie były przeznaczone dla obcych, miały strukturę hermetyczną i nie rozprzestrzeniały się na inne społeczności - nazwiemy je grami zamkniętymi (Hall 2011, s. 145-168). W opozycji do nich znajdą się rozgrywki o charakterze powszechnym, a więc otwarte, których praktykowanie podlegało ewolucji i przenikaniu w inne niż wyjściowe środowiska. Szukając porównań, można zaproponować analogię do wierzeń i kultów, co ma swoje umocowanie w związku z powstawaniem gier opierających się na sferze sacrum. Kult lokalny danej społeczności czy plemienia, podobnie jak gra zamknięta, był formą tłumaczenia jej odrębności i umocowania w otaczającym świecie. Gra otwarta z kolei będzie zbliżona do kultu posługującego się kategoriami uniwersalnymi, które na tereny słowiańskie wniosło dopiero chrześcijaństwo (Strzelczyk 2010, s. 10-11). Ważne jest zatem prawidłowe określenie w badanym materiale przedmiotów będących bierkami stosowanymi w grach. Często bowiem przybory używane w skandynawskiej grze hnefatafl są mylone z szachami, co zaburza rzeczywisty obraz znajomości obu form. Zgodnie z powyższymi uwagami ma to zasadnicze znaczenie, gdyż pojawienie się obiektów należących do pierwszej z nich wskazuje określone, ściśle zamknięte środowisko użytkowników, natomiast przybory związane z drugą mają już odmienny charakter. Są to istotne kwestie, które przy odpowiednim rozgraniczeniu znalezisk pozwalają na wykazanie ważnych aspektów kulturowych w badanych materiałach (Stempin 2008, s. 195-2009).

Zatem przystępując do omawiania średniowiecznych znalezisk wiązanych z szachami, odkrytych na terenie ziem polskich, należy przyjąć, że funkcjonujące w literaturze tematu określenia przypisujące najwcześniejszą recepcję tej gry rejonom Pomorza są nieprawidłowe (np. Rulewicz 1961, s. 18-24; Hensel i Pazdur 1977, s. 314-316; Giżycki 1984, s. 6). Na północy Polski bowiem w X-XI wieku, jak 
wynika z dostępnego materiału różnych pionów, grano w hnefatafl, będącą częścią wierzeń i bogatej sfery sacrum kultury skandynawskiej. Jej ważkość podkreślają liczne sagi (Słupecki 1998, s. 124; Bubczyk 2005, s. 27) oraz znaleziska pełnych kompletów bierek w najważniejszych centrach wczesnośredniowiecznego świata łączonego z osadnictwem i penetracją skandynawską (Batey i Clarke 1998, s. 64; Rundkvit i Williams 2008, s. 69-101). Od IX wieku hnefatafl towarzyszyła Skandynawom na terenie Rusi, gdzie odkryto tego typu bierki na stanowiskach w Starej Ładodze, Gniezdowie czy Rurykowym Gorodiszczu (Duczko 2006, s. 76 - tam dalsza literatura). Tego typu znaleziska wystąpiły łącznie z bogatym zestawem zabytków pozwalających na ustalenie, że jest to pozostałość kompleksowej kultury skandynawskiej (Duczko 2006, s. 89). Problematyka styku, jaki w okresie około XI wieku nastąpił pomiędzy rodzimą grą wikińską a nową, rozpowszechniającą się właśnie formą rozgrywek, czyli szachami, jest tematem dyskutowanym w ostatnich latach i stanowi ciekawą problematykę badawczą (Schulte 2017, s. 1-42).

Przechodząc do kwestii ściśle szachowej, należy stwierdzić, że początki tej gry większość badaczy sytuuje w Indiach. Rozprzestrzeniały się one od VI-VII wieku na terenie Azji, a na kontynent europejski dotarły za sprawą ekspansji arabskiej, choć pierwsze ślady ich obecności w źródłach pisanych i znaleziskach bierek znane są tu dopiero od wieku X (Eales 2001, s. 9-70). W literaturze zwraca się uwagę na sferę terminologii wczesnych faz adaptacji gry w Europie, która wykazuje wiele wspólnych cech z nazewnictwem stosowanym przez muzułmanów (Eales 2001, s. 41). Jednak problem, kiedy i gdzie nastąpił ten kontakt ze światem arabskim, który zadecydował o przyjęciu orientalnej nowinki na gruncie europejskim, jest wciąż nierozstrzygnięty. W łacińskich źródłach pisanych pierwsze sformułowania dotyczące szachów pojawiają się dość późno, w czasie kiedy Arabowie obecni byli już w północnej Afryce, Hiszpanii, południowej Francji, na Sycylii i w południowych Włoszech. W Stiftsbibliothek w szwajcarskim Einsiedeln znajduje się tzw. Eisiedeln manuscript (sygn. 319, 365), będący zbiorem różnych rękopisów, luźnych kart, z których nr 94 i 95 zawierają fragmenty poematu Versus scaschis (Gamer 1954, s. 734-750). Jest to najstarszy, datowany na lata 990-997, tekst źródłowy mówiący o szachach w Europie łacińskiej. Co ciekawe, gra nie stanowi tam nowinki, można rzec, że spełnia rolę przewodnią, będąc jednym z głównych wątków. Istotny jest również fakt, że użyta w omawianym poemacie terminologia to zmodyfikowane i przetransponowane na grunt europejski nazewnictwo, świadczące nie tylko o dobrej znajomości samych rozgrywek, ale przede wszystkim o świadomym wyborze właśnie szachów do zilustrowania toczącej się w 98 wersach intrygi. Szachy poza doskonale wyjaśnionymi zasadami gry przedstawiono tam w opozycji do gier losowych, dowodząc ich wyższości (Yalom 2005, s. 16-17). Wiemy zatem, że pod koniec $\mathrm{X}$ wieku gra w szachy znana była już dobrze na południu obecnej Szwajcarii, gdzie nie tylko posłużyła jako wątek stworzonej historii, ale - co ważniejsze - anonimowy mnich, korzystając prawdopodobnie $\mathrm{z}$ arabskich rękopisów, zastosował określenia świadczące o zakorzenieniu 
i zaadoptowaniu całej sfery dotyczącej tego typu rozgrywek w jego środowisku. Wiedzy o znajomości szachów w początkach XI wieku dostarczają nam również dokumenty z terenu Hiszpanii. Wydany pomiędzy 1008 a 1010 rokiem testament Ermengauda I, hrabiego Urgel (hiszpańska marchia królestwa Francji), zawiera zapis donacji drogocennych szachów opactwu St. Giles (najprawdopodobniej w Nimes) w zamian za modlitwę (Gamer 1954, s. 738; Bubczyk 2009, s. 116). Same szachy trafiły tam prawdopodobnie w 1010 roku, kiedy to hrabia poległ w bitwie. Kolejne donacje na rzecz klasztoru św. Idziego, ekskluzywnych kompletów szachowych z kryształu górskiego, pojawiają się pół wieku później dzięki tej samej rodzinie. Szachy, szczególnie wykonane z kosztownych surowców, w opactwie spełniały rolę spolium i służyły już $\mathrm{w}$ innej formie bądź to $\mathrm{w}$ dekoracjach relikwiarzy i mebli czy sprzętów liturgicznych, bądź stanowiły o bogactwie skarbców katedralnych (Taussaint 2012, s. 177-202; Tabor 2016, s. 177-202), a w wyjątkowych sytuacjach mogły być również użytkowane.

W północnej Europie najwcześniejsza nota dokumentująca znajomość szachów znajduje się w informacji o darze, jakiego dokonał prefekt Grenlandii - Gunner dla króla norweskiego Haralda Haardraada (1040-1067). Podarunkiem był ekskluzywny komplet szachów wykonany z kłów morsa oraz biały niedźwiedź, dzięki którym darczyńca chciał zyskać przychylność monarchy (Goldschmidt, 1926, IV.7; Gamer 1954, s. 739). Na terenie Cesarstwa Niemieckiego źródła pisane dotyczące znajomości gry w szachy pojawiają się $\mathrm{w}$ drugiej połowie XI wieku, a gra jawi się tam bardzo dojrzale - w poemacie Ruodlieb (MS. Clm. 19 486), spisanym około 1070 roku w klasztorze Tergernsee przez anonimowego mnicha (Murray 1913, s. 411, 415, 475; Gamer, 1954, s. 740). Wiemy również, że szachy znane były pod koniec XI wieku w Czechach. Quatuor immensi, anonimowa łacińska legenda opowiadająca historię męczeństwa św. Wojciecha, wspomina grę w szachy jako czczą rozrywkę, której męczennik nigdy nie ulegał. Mniej więcej w tym samym czasie, najprawdopodobniej około 1083 roku, Wiprecht von Groitzsch otrzymał od księcia Wratysława II (w podzięce za opiekę nad oddziałami czeskimi wspierającymi cesarza Henryka II w wyprawie włoskiej) niezwykle ekskluzywną szachownicę wraz z kompletem figur, o której będzie jeszcze mowa w dalszym toku rozważań. Jak sugeruje Wojciech Iwańczak, być może podarunek był efektem ożywionych kontaktów z Italią, gdzie szachy znane były w tym czasie powszechnie zarówno arystokracji, jak i duchowieństwu (Iwańczak 2001, s. 454-455). We Włoszech jednak pierwsze świadectwo dotyczące szachów nie jest dla gry przychylne. Świadczy co prawda o jej dużej popularności, ale z dokumentu pochodzącego z 1061 lub 1062 roku wnioskować można, że nie wszystkim to się podobało. Kardynał i biskup Ostii Peter Damiani wyraża w liście do papieża-elekta Aleksandra II i Arcydiakona Hildebrandta swoje oburzenie na uleganie hazardowi przez niektórych dostojników kościelnych, przede wszystkim biskupa Florencji (szachy zaliczone zostały do gier hazardowych alea, i nie przyjęto thumaczenia oskarżonego, że gra przebiegała bez użycia kości [Gamer 1954, s. 739; 
Bubczyk 2009, s. 116, 204-205]). W łacińskiej Europie w początkach XI wieku mamy zatem do czynienia ze źródłami, w których spotkać można skrajne opinie na temat wartości poświęcania czasu na rozgrywki szachowe. Ambiwalentne postawy w tej kwestii, wyrażane przez różne środowiska - szczególnie duchownych - będą obecne przez całe średniowiecze, jednak już w początkach XII wieku zwolennicy gry zwrócili uwagę na istotną rolę, jaką szachy mogą odegrać w wychowaniu młodzieży. Poszukiwanie narzędzi, dzięki którym ma się wpływ na kształtowanie pozytywnych wzorców spędzania wolnego czasu, skierowało uwagę na gry tablicowe. Podkreślano ich znaczenie w rozwoju intelektualnym, możliwość łatwiejszego zapamiętywania ważnych kwestii poprzez znaki i symbole im towarzyszące, a także atmosferę panującą podczas rozgrywek sprzyjającą rozwijaniu kontaktów towarzyskich i dyplomatycznych. Wzorem orientalnych tradycji (Bubczyk 2009, s. 34), a także doświadczeń antycznych (Adamczyk 2012, s. 41; Stempin 2012a, s. 5-19) czy skandynawskich (Bubczyk, 2009, s. 74-77), gdzie grom przypisywano duże znaczenie w kształceniu władców, szachy stały się również częścią kultury dworskiej. W jej ramach wykształciły się podczas XII wieku reguły postępowania, zachowania, a także zestaw umiejętności wpisujących się w całokształt edukacji, które w konsekwencji stały się wyróżnikiem rycerstwa. Stan identyfikowano poprzez odrębne obyczaje, takie jak: pasowanie na rycerza, posiadanie herbu i zawołania, ale też odpowiednie wychowanie, którego istotnym elementem już od XI/XII wieku były takie aktywności, jak: jazda konna, pływanie, posługiwanie się łukiem, polowanie z sokołem i gra w szachy, o czym przekonuje hiszpański lekarz Patrus Alfonsi w dziele De disciplina clericalis (Bubczyk 2009, s. 34-36). Ślady popularności szachów są bardzo liczne, odnotowano je zarówno w literaturze łacińskiej, jak i początkach piśmiennictwa w językach narodowych. Erudyta szachowy i historyk tej gry Harrold Murray (1913, s. 418) uważał, że obecność tematyki związanej z szachami manifestuje się w trzech rodzajach źródeł pisanych tego okresu. Do pierwszej zaliczył jednoznacznie dydaktyczne dzieła, które najlepiej reprezentuje utwór Aleksandra Neckhama De scaccis (około 1180 roku), następnie moralitety, wśród których najbardziej znanym autorem jest dominikanin Jacub de Cessolis, i dzieło Liber de morribus hominum et officius nobilum (około 1300) oraz specjalistyczne prace dotyczące problemistyki szachowej oparte zazwyczaj na manuskryptach arabskich, cieszące się szczególnym uznaniem po 1250 roku, a z których najistotniejsze znaczenie ma dzieło powstałe dla Alfonsa X Mądrego z 1283 roku pt. Libros del Axedrez, Dados et Tablas (Golladay 2007; Fajardo-Acosta 2015, s. 489-523) (ryc. 1).

\section{POCZĄTKI ZNAJOMOŚCI GRY W SZACHY NA TERENIE POLSKI}

Świadomość istotnego znaczenia rozgrywek jako wzorca kulturowego stawia także w nowym świetle problem ich przenikania do innych społeczności. Jest 


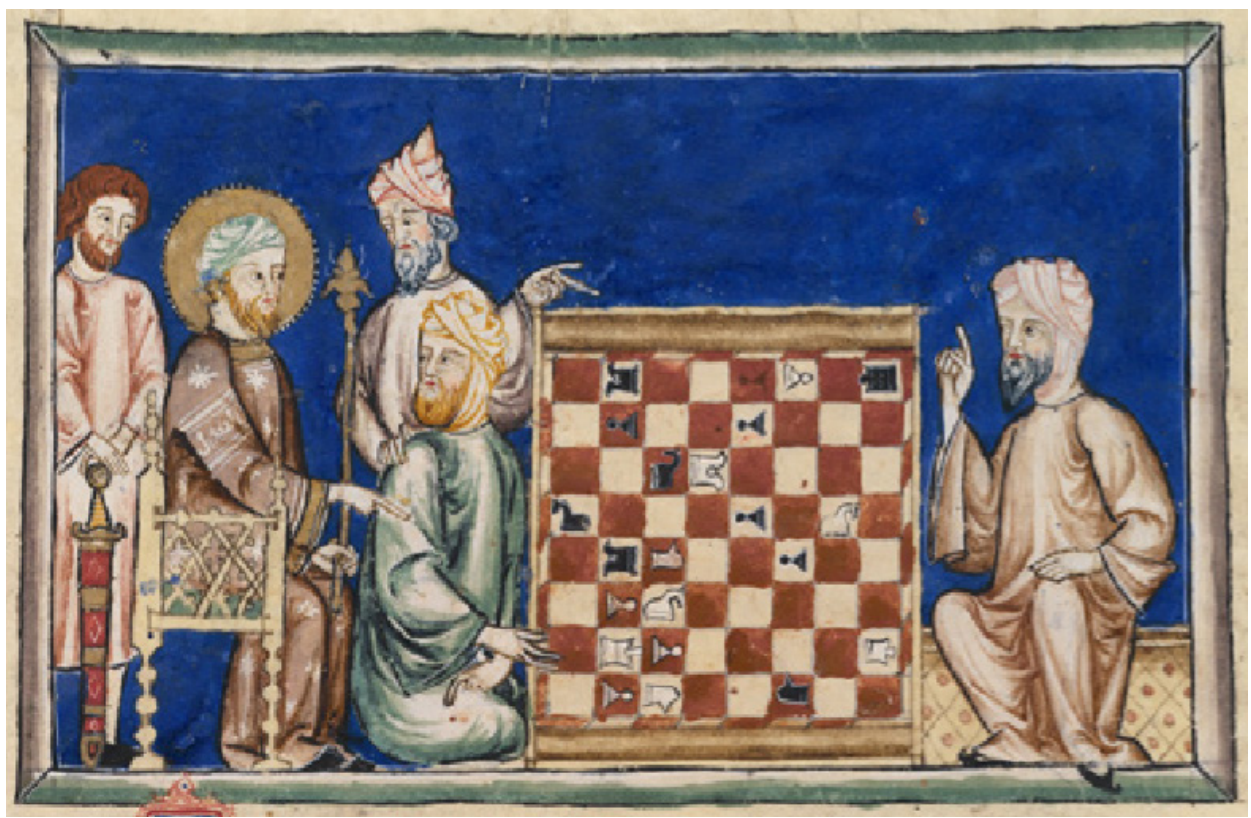

Ryc. 1. Gra w szachy preentowana królowi. Libro de los Juegos. Ms F_17v. Biblioteca del Real Monasterio de El Escorial, wg Schädler i Calvo 2009, s. 106

bowiem nie tylko miernikiem ich atrakcyjności rozrywkowej, ale także pokazuje, że recepcja tych elementów na coraz to nowych obszarach, była jednocześnie formą propagowania idei i treści kulturowych.

Odkrywane na terenie wczesnośredniowiecznych stanowisk bierki szachowe oraz źródła pisane dowodzą, że szachy, będące wytworem obcym kulturowo, stawały się częścią kanonów zachowania i postrzegania w nowych środowiskach, a więc także na obszarze młodego państwa polskiego. Pierwsze wzmianki w źródłach pisanych dotyczących Polski, pojawiają się dopiero od pierwszej połowy XIV wieku. Jan Długosz podczas omawiania wypadków 1333 roku wspomina herb Roch (na czerwonym polu wieża szachowa): „Był zaś Klemens rodem Polak, herbu Pierzchała, co ma za godło marszałka szachowego, inaczej rocha", i jest to najstarsza wzmianka pisana na temat szachów w Polsce (Bubczyk 2003, s. 9). Wiele cennych informacji dotyczących znajomości szachów na naszych terenach odnajdujemy pośrednio dzięki legendom herbowym, choć te świadectwa również należą do źródeł późnych. Szachownice i figury szachowe są elementami składowymi herbów Wczele i Pierzchała (Bubczyk 2003, s. 8; Wiesiołowski 1993, s. 13-23). Najwcześniejszą metrykę (XII wiek) mają herby księstwa legnicko-wrocławskiego, proporce księstwa legnicko-brzeskiego oraz herby domów Piastów śląskich zawierające wyobrażenie szachownicy (Bubczyk 2003, s. 9). Nie jest to jednak 
jednoznaczne z grą w szachy, choć bardzo uprawdopodobnia jej znajomość w tych kręgach. Bazując na źródłach pisanych, zmuszeni bylibyśmy przyjąć stosunkowo późne datowanie znajomości szachów w społeczności polskiej. Sytuacja taka wydaje się mało prawdopodobna tym bardziej, że zachowane informacje grę traktują jako niewymagającą tłumaczenia, umiejscawiając jako tło wydarzeń, co sugeruje, że mamy do czynienia $\mathrm{z}$ umiejętnością dobrze znaną. W tym kontekście bardzo istotna wydaje się rola odkryć archeologicznych.

\section{FORMY BIEREK SZACHOWYCH}

W historii rozwoju bierek szachowych wyróżnić można dwa podstawowe nurty związane z kształtem i charakterem tych przyborów, które stały się podstawą kolejnych przemian, a ich kontynuacja jest obserwowana na wszystkich obszarach adaptacji gry. Pierwszy, najstarszy styl określa się mianem realistycznego lub inaczej figuratywnego. Szachy od momentu powstania około V-VI wieku produkowano jako minirzeźby rzeczywistych postaci związanych wizualnie ze strukturami hinduskiego wojska. Najstarszy przykład 27 takich bierek pochodzi z uzbeckiego stanowiska w Afrasjabie (dawna Samarkanda) (Buriakow 1980, s. 162-172; Eder 1994, s. 71-78; Contadini 1995, s. 111; Fahid 2018, s. 14) (ryc. 2a). Zupełnie odmienny jest styl muzułmański (określany również jako geometryczny lub arabski). Początki tej stylistyki datowane są na VIII wiek, a najstarsze znane figury tego typu odkryto w północno-wschodnim Iranie, w miejscowości Nishapur (IX wiek) (Fahid 2018, s. 23) (ryc. 2b). Powodem, dla którego w środowisku muzułmańskim zaniechano produkcji realistycznych figur, był obowiązujący w ortodoksyjnym islamie zakaz przedstawiania oblicza Boga oraz postaci ludzkich i zwierzęcych (czyli ożywionej rzeczywistości), co było traktowane jako bałwochwalczy akt konkurencyjny do boskiego stworzenia ${ }^{1}$. Dzięki strukturze geometrycznej figur arabskich osiągnięto uniwersalizm przekazu, a to niewątpliwie pomogło w upowszechnieniu znajomości gry w sferach mniej zamożnych. Bierki w stylistyce arabskiej wpisane zostały w geometryczną strukturę walca, na której w sposób umowny zaznaczano charakterystyczne cechy danej postaci lub zwierzęcia (ryc. 3g). Król w wersji persko-indyjskiej to mężczyzna siedzący na słoniu, teraz stał się kulistym wybrzuszeniem górującym nad walcem z symbolicznie wyciętym korpusem zwierzęcia. Hetman wyglądał identycznie, miał nieco mniejsze rozmiary, a w niektórych przypadkach pozbawiony był wieńczącej kulki. Analogicznie, rycerz konny zmienił się we fragment stożka z pojedynczym występem imitującym koński łeb (lub jak wolą inni - jeźdźca). Słonie bojowe reprezentowała podobna forma różniąca się tylko tym, że występy były dwa - jak kły słoniowe.

\footnotetext{
${ }^{1}$ Pierwsza wzmianka o ikonoklazmie $\mathrm{w}$ islamie zawarta jest $\mathrm{w}$ edykcie wydanym przez kalifa umajjadzkiego Jazida II z roku 724 (Wąs 2008, s. 8).
} 

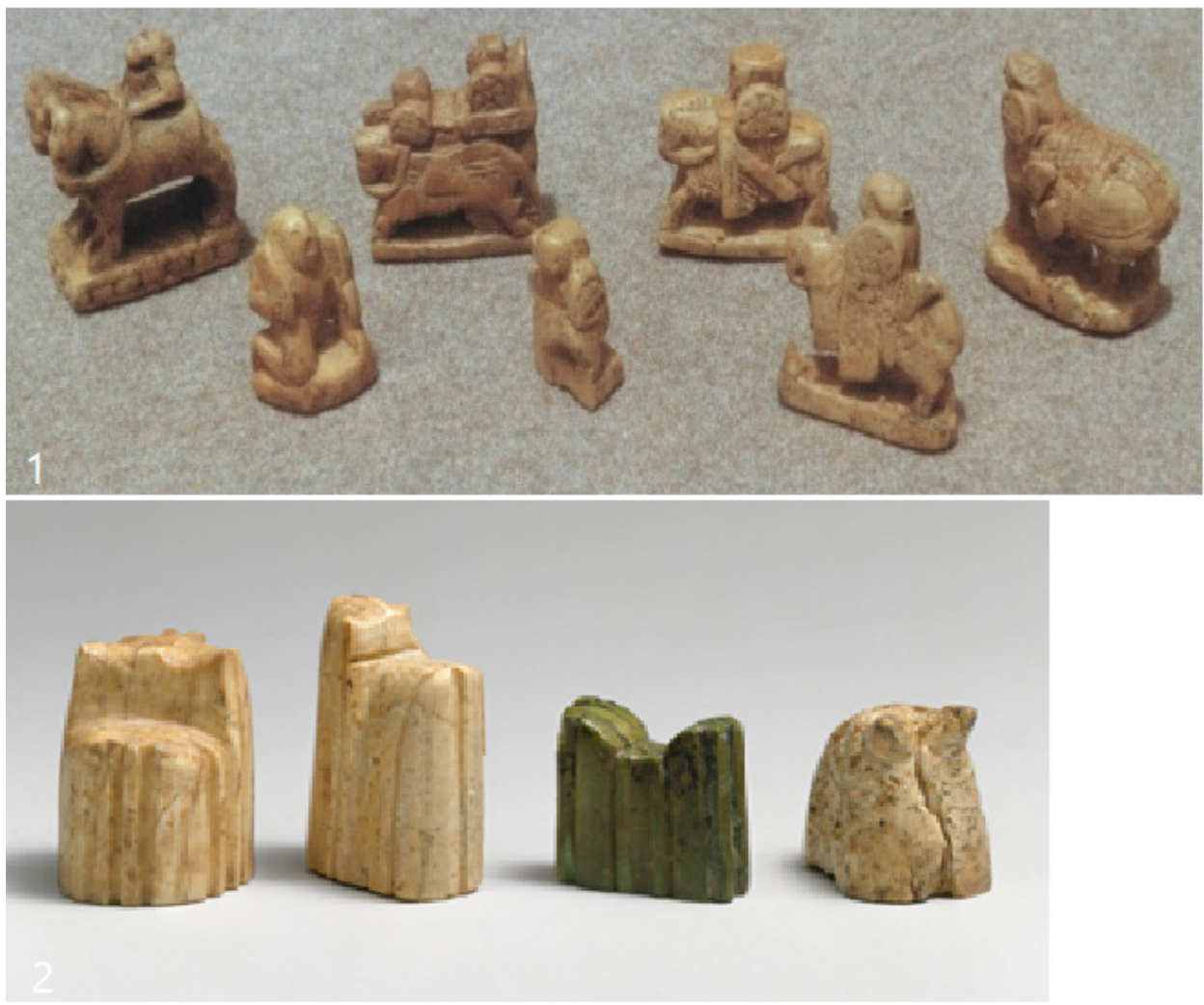

Ryc. 2. Najstarsze figury szachowe dwóch głównych nurtów stylistycznych: a. Afrasjab VII w. styl realistyczny, figuratywny, wg Eder 1994, s. 72-74, ryc. 17-22); b. Nishapur, VIII-IX w. styl abstrakcyjny, muzułmański, wg Fahid 2018, s. 23

Ostatnia figura (w dzisiejszej terminologii wieża), wówczas wóz bojowy, wpisana została w kształt prostopadłościanu z asymetrycznym, trójkątnym wcięciem w górnej partii - prezentującym wnętrze rydwanu. Wszystkie pionki miały kształt ściętego i górą zaokrąglonego stożka, w warstwie znaczeniowej zaś były piechotą (ryc. 3a-f). Styl figuratywny, który wymuszał znacznie większe nakłady pracy i wymagał wyspecjalizowanych umiejętności, uznawany był za ekskluzywny. Przetworzona przez muzułmanów forma szachów (figur szachowych, ale również reguł) na zachód Europy przenikała przez dwie strefy transferowe: Półwysep Iberyjski i południowe Włochy, natomiast na tereny wschodniej Europy szlakiem nadwołżańsko-kaspijskim (ryc. 4). Adaptacja gry w szachy na terenie Europy nie przebiegała w sposób jednolity, czego konsekwencją jest bardzo wyraźne zróżnicowanie przedmiotów służących jej uprawianiu. Zachód Europy dokonał na szachach swoistej operacji, wycinając $\mathrm{z}$ pierwotnego podłoża znaczeniowego i tworząc na tym szkielecie nową jakość, zastępując wojnę obrazem społeczeństwa, adaptując grę do 

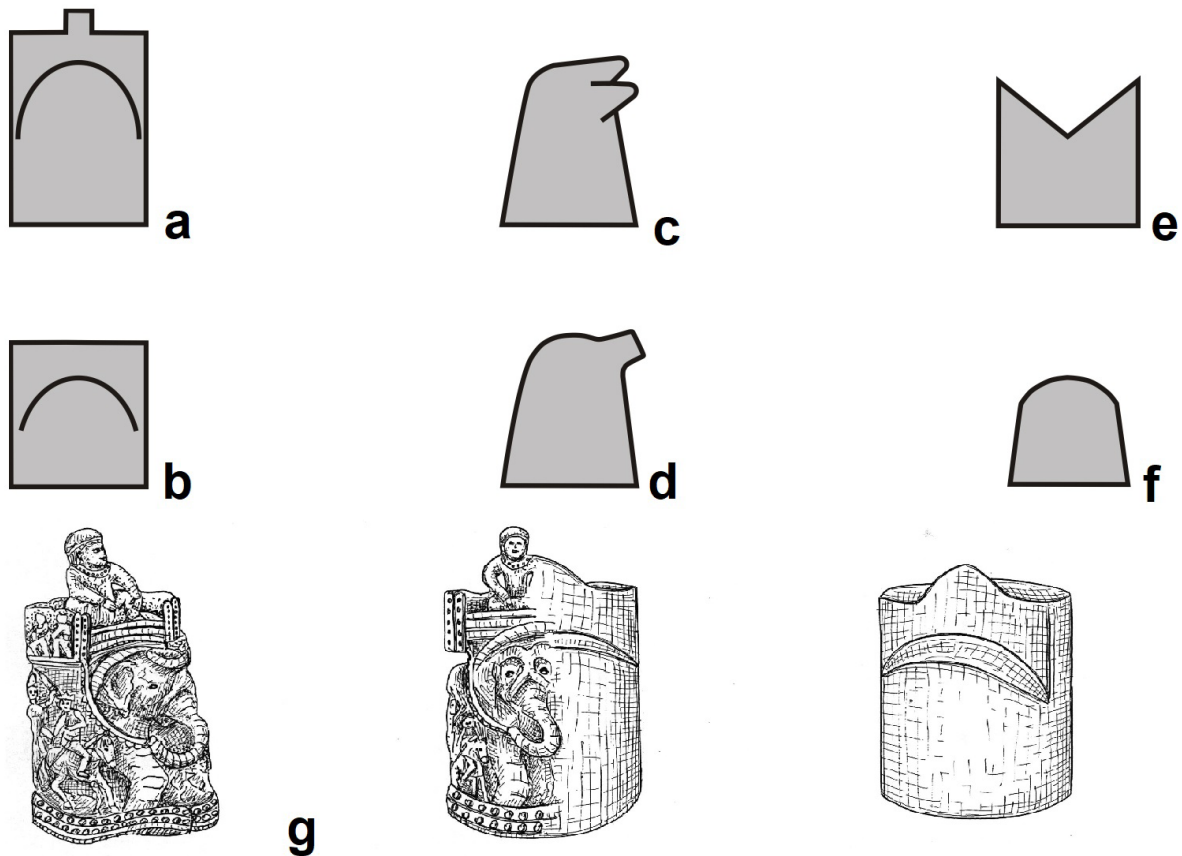

Ryc. 3. Ewolucja stylistyki figuratywnej (indyjsko-perskiej) do przedstawień abstrakcyjnych, geometrycznych (arabskich). Rys. J. Kędelska

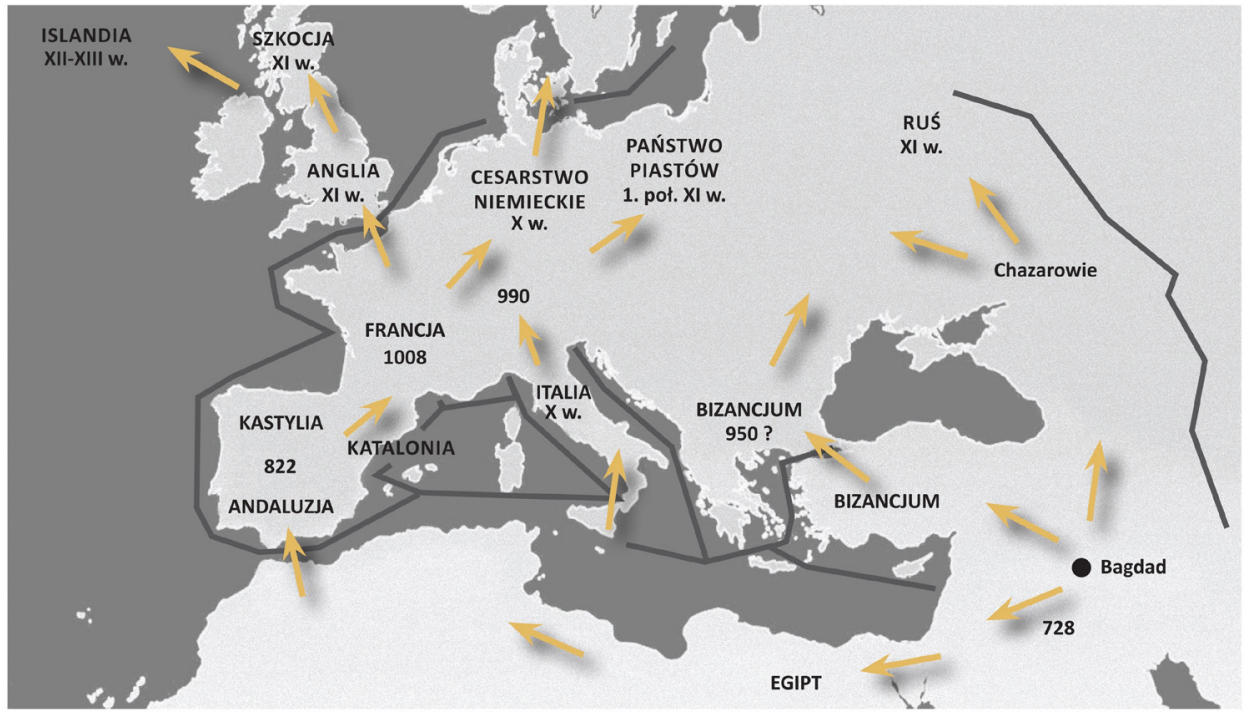

Ryc. 4. Kierunki napływu znajomości gry w szachy i najstarsze jej świadectwa w poszczególnych regionach. Opr. A. Stempin na podstawie J.L. Cazaux 2012, s. 56, ryc. 3 
objaśniania rzeczywistości swoich czasów, relacji między poszczególnymi stanami oraz budowania poczucia wartości i etyki rozwijanej w ramach metaforyki moralizatorskiej (Karłowska-Kamzowa 2000; Hojdis 2000). Stąd na szachownicach łacińskich stanęły królowe (zstąpiły dowódców wojsk wschodnich, tzw. vizirów), biskupi (którzy zajęli miejsce hinduskich słoni) i wieże szachowe (dzięki którym pozbyto się wozów bojowych - rydwanów, stosowanych w armiach orientalnych). We wschodniej Europie, będącej pod wpływem kultury bizantyńskiej, ale też kształtowanej przez społeczność skandynawską, adaptacja szachów dokonała się ze zmianami jedynie kosmetycznymi, pozostawiając je w kręgu zmagań wojennych. Odzwierciedleniem tych odrębności jest do dziś terminologia (tab. 1).

Tabela 1. Słownictwo użytkowane w poszczególnych językach na tle ówczesnego znaczenia i terminologii dzisiejszej. Opracowano na podstawie: Eales 2001, s. 23

\begin{tabular}{|c|c|c|c|c|}
\hline Język perski & Język arabski & Znaczenie ówczesne & $\begin{array}{c}\text { Termin dzisiejszy } \\
\text { łacińska Europa }\end{array}$ & $\begin{array}{c}\text { Termin dzisiejszy } \\
\text { wschodnia Europa }\end{array}$ \\
\hline Chatrang & Shatranj & Szachy & Szachy & Szachmaty \\
\hline Shah & Shah & Król & Król & Vizir \\
\hline Farzin & $\begin{array}{c}\text { Firzan oraz Firz } \\
\text { (później Vizir) }\end{array}$ & Doradca & Goniec/Biskup & Słoń \\
\hline Pil & Fil & Słoń & Koń/Rycerz/Skoczek & Koń \\
\hline Asp & Faras & Koń/Jeździec konny & Wieża & Ładja (łódź) \\
\hline Rukh & Rukh & Wóz bojowy & Pionek & Pieszka \\
\hline Pujada & Baidag & Pieszy wojownik &
\end{tabular}

Formy i wygląd bierek szachowych są obecnie ujednolicone na całym świecie, natomiast $\mathrm{w}$ średniowieczu - w początkowych stadiach adaptacyjnych - różniły się znacznie właśnie ze względu na odmienną nomenklaturę i sposób rozumienia poszczególnych jednostek na szachownicy. Szczególnie czytelne jest to w materiale z okresu od XI do XIII stulecia w szachach typu figuratywnego. W mniejszym zakresie rejestruje się te różnice w klasycznych formach abstrakcyjnych muzułmańskich, choć i tam można wskazać pewne typowe dla poszczególnych rejonów tendencje.

POCZĄTKI ADAPTACJI GRY W SZACHY NA TERENIE POLSKI NA PODSTAWIE WYBRANYCH PRZYKŁADÓW ŚREDNIOWIECZNYCH BIEREK SZACHOWYCH

Analiza materiału archeologicznego dotyczącego recepcji szachów na terenie Polski pozwoliła na stwierdzenie dużo wcześniejszej obecności przyborów służących tej grze, niż to wynika z przekazów pisanych (Stempin 2018a, s. 31-53), gdzie umiejętność ta po raz pierwszy pojawia się dopiero w 1. połowie XIV wieku 


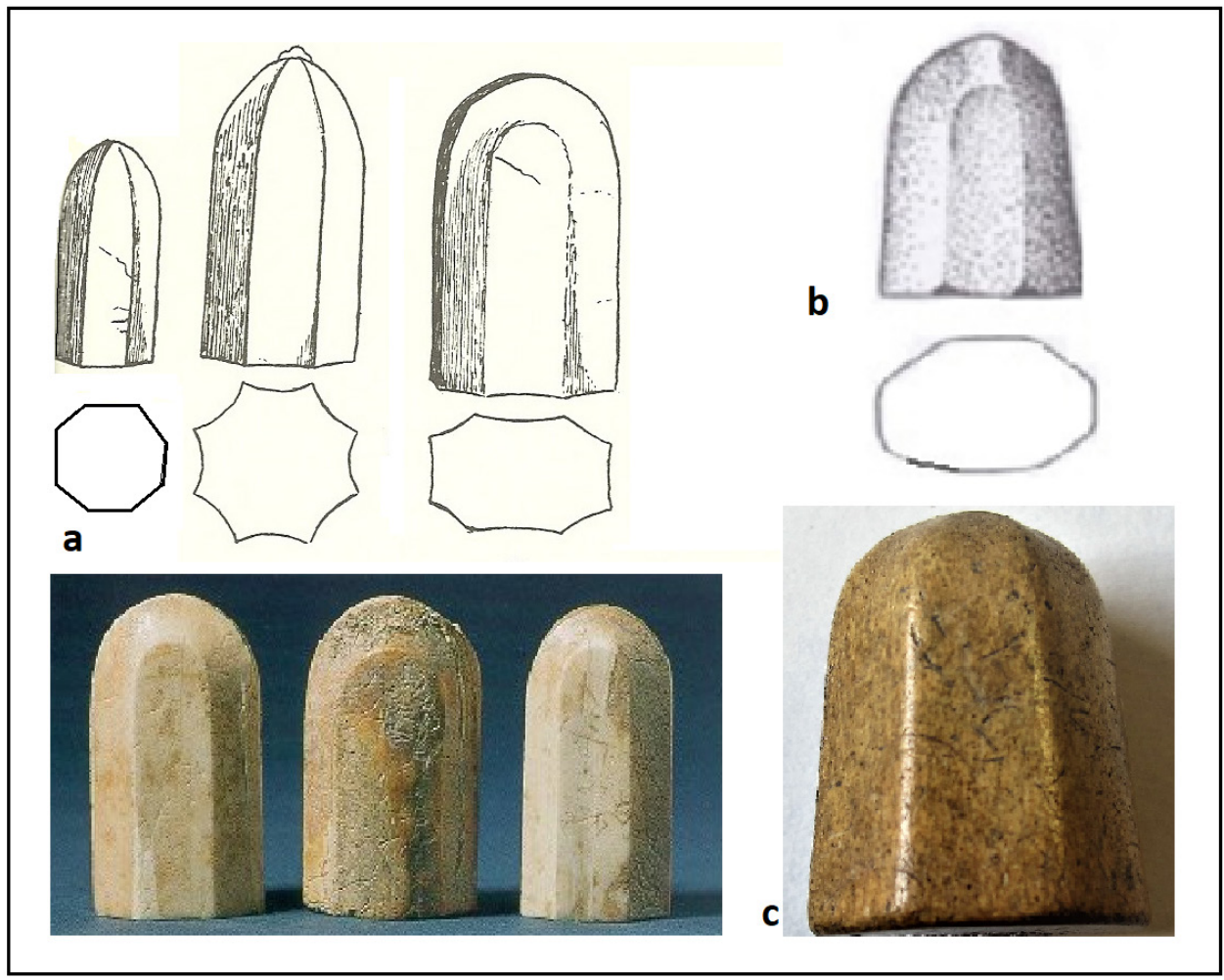

Ryc. 5. Pionki fasetowane: a. pionki z kompletów wykonanych z kłów morsa, odkrytych na szkockiej wyspie Lewis (rys. wg Murray 1913, s. 763, fot. British Muzeum); b. pionek wrocławski (wg Jaworski 1990, s. 42-3, ryc. XIg); c. pionek z Santoka, fot. K. Zamelska-Monczak

podczas wypadków z 1333 roku omawianych w Annales Jana Długosza. Zgodnie z tymi obserwacjami, najstarsze ślady bierek szachowych rejestruje się w 1. połowie XI wieku i kumulują się one w ośrodku wrocławskim. Zwraca tam uwagę ciągłość ich występowania w kolejnych poziomach chronologicznych, a także fakt obserwowania na tamtejszych figurach zmian stylistycznych, jakim podlegały szachy na terenie łacińskiej Europy (Jaworski 1990, s. 42-43; Stempin 2018a, s. 33-35). Najstarsze europejskie wzmianki źródłowe potwierdzające posiadanie zestawów do gry w szachy pochodzą z donacji testamentowych z terenu Hiszpanii i datowane są na 1. połowę XI wieku. W tym samym czasie na wrocławskim Ostrowie Tumskim rejestruje się formy figur wzorowane na kosztownych bierkach z kryształu górskiego. Dowodzą tego znaleziska z podgrodzia, z obiektu określonego jako budynek nr 4, gdzie od 1. ćwierci do 2. połowy XI wieku zarejestrowano trzy piony, z których jeden, o podstawie oktagonalnej, bez wątpienia użytkowany był w grze w szachy (Stempin 2018a, s. 37) (ryc. 5b). Idea oktagonalnych bierek 


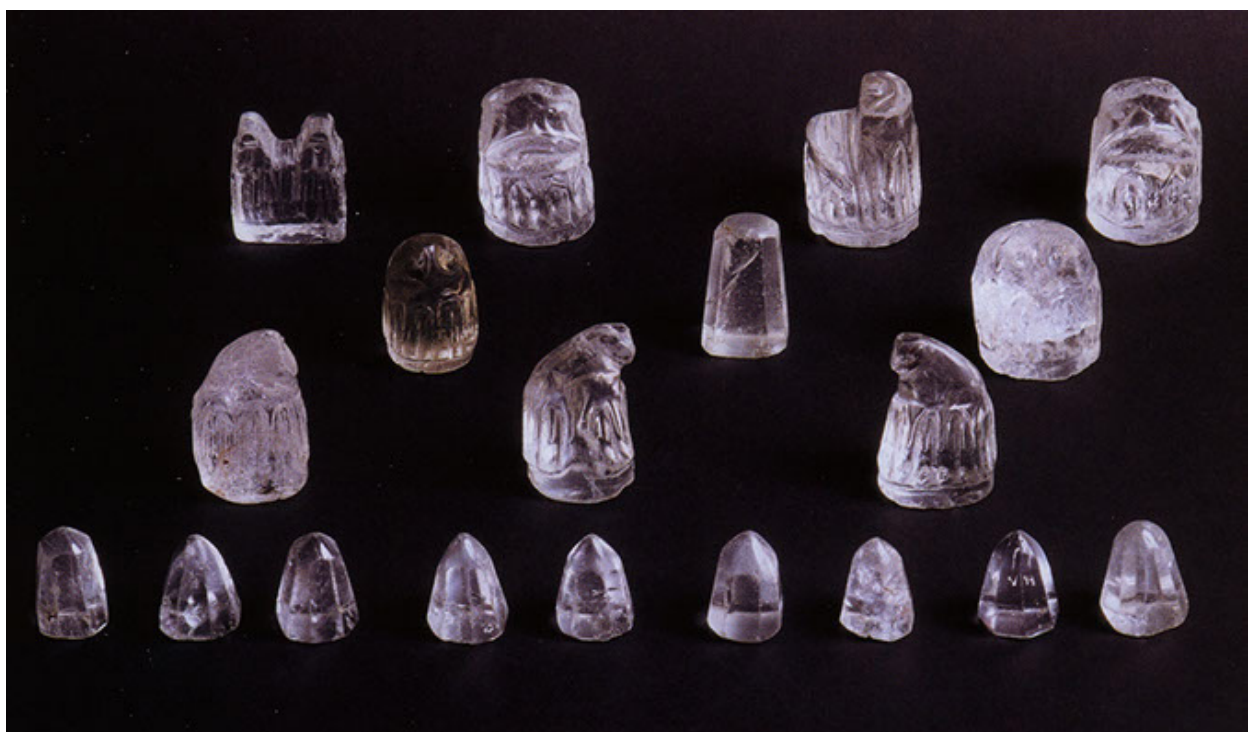

Ryc. 6. Figury szachowe z kryształu górskiego, St Pere d’Àger (wg Kluge-Pinsker 1991, s. 35)

szachowych i ich najstarsze przykłady pochodzą z kompletów wykonanych w stylistyce abstrakcyjnej muzułmańskiej z kryształu górskiego, w których wykorzystywano strukturę samego surowca (ryc. 6). Pojawiają się one w donacjach testamentowych w północnej Hiszpanii od początku XI wieku. Jeszcze wcześniej, bo już na przełomie X i XI wieku wykorzystano pojedyncze egzemplarze z kryształu górskiego w trzech katedrach niemieckich: Halberstadt, Osnabrück oraz Münster. Ich obecność jest wiązana tam z okresem rządów młodego cesarza Ottona III, w czasie od 996 do 1002 roku, i nawiązaniu do idei renowacji Imperium Romanorum, w której szachy zaczęły odgrywać niebagatelną rolę. Liczne kościelne fundacje cesarskie, wymagające relikwii sprawiały, że tego typu drogocenne przedmioty (znajdujące się prawdopodobnie w skarbcach wcześniej) wykorzystywane były do udekorowania i wzbogacania powstających obiektów. Aktualnie ta hipoteza jest uznawana za najbardziej prawdopodobną (Fahid 2018, s. 163-175, 316-318), chociaż nie brak głosów, jakoby same figury z kryształu górskiego stanowiły dary pielgrzymów lub krzyżowców, jak miało to miejsce w przypadku klasztorów szwajcarskich (Schadler 2008, s. 657). Zaznaczyć należy, że obie te możliwości nie wykluczają się wzajemne, a publiczne wystawianie relikwii zdobionych kameryzacją, w której wykorzystywano bierki szachowe, w tym pionki w roli kamieni szlachetnych, popularyzowało te kształty. Znajomość ekskluzywnych szachów z kości słoniowej i kryształu górskiego w bezpośredniej bliskości polskich granic jest poświadczona w roku 1096, kiedy to hrabia Wiprecht de Groitzsch ofiarował kilka figur obu rodzajów klasztorowi benedyktynów St. Jakobus de Pegau 
koło Lipska w Saksonii „do dekoracji ambony”. Wspominaliśmy już o tym, że wcześniej prawdopodobnie te same szachy otrzymał właśnie za zasługi wojenne. Tymczasem donacji tej dokonał po powrocie z pielgrzymki do Rzymu i Composteli, aby odpokutować za zadawaną przemoc. Gest ten zapisany został w lokalnych kronikach około 1155 roku i jest prawdopodobnie świadectwem sławy Aix-la-Chapelle, gdzie ambonę taką wcześniej ufundował Henryk II, król Niemiec, a którą do dziś można tam podziwiać (ryc. 7). Wiprecht zamanifestował wolę oddzielenia się od swojej militarnej przeszłości szachami, które prawdopodobnie odziedziczył po teściu, królu Czech Wratysławie II (Cordez 2011, s. 108). Pionki o podstawach oktagonalnych lub w późniejszym okresie heksagonalnych, względnie heptagonalnych, stały się charakterystycznym elementem szachów początkowo tworzonych wyłącznie w stylistyce muzułmańskiej, a już od XII/XIII wieku używano tych kształtów również w przypadku szachów figuratywnych. Najbardziej spektakularnym przykładem są tu pionki wykonane z kłów morsa pochodzące z kompletów odkrytych na szkockiej wyspie Lewis z 1. połowy XIII wieku (Caldwell, Hall i Wilkinson 2009, s. 34). Jak zaobserwował Ian Riddler, badający bierki szachowe z Wysp Brytyjskich, pionki oktagonalne (fasetowane) są średnio smuklejsze, wyższe (nawet dwukrotnie) niż inne (Riddler 1995, s. 105). Uznaje je jednocześnie za należące do ekskluzywnych kompletów niezależnie od surowca, z jakiego są wykonane (Riddler s. 108). O tym, że często sięgano do tych wzorców, może świadczyć przykład ze stanowiska Loisy (Francja), gdzie szachy datowane radiowęglowo pomiędzy 910 a 976 rokiem stanowiły wyposażenie rezydencji możnowładczej, a odkryte pionki, podobnie jak wrocławskie, wykonane były z poroża jelenia i miały takie same fasetowane ścianki (Goret, Talon i Yvinec 2009, s. 85; Grandet i Goret 2012, s. 128-129). Innym wczesnym przykładem zbliżonym zarówno formą, jak i surowcem do pionków znanych ze zbiorów polskich jest bierka z poroża jelenia odkryta w Stade. Pionek ten o przekroju sześciokątnym datowany jest na połowę XII wieku (Nagel 1986, s. 81-86). Pojawienie się tego nurtu tak wcześnie jak na wrocławskim grodzie (2. ćwierć XI wieku) świadczy o bardzo szybkim docieraniu na teren Śląska najbardziej znanych i ekskluzywnych wzorców w dziedzinie gier. W zbiorach polskich zidentyfikowano dotychczas cztery tego typu piony szachowe, jednak tylko wrocławski ma tak wczesną chronologię. Pozostałe egzemplarze pochodzą: z Gniezna (Sawicki 2016, ryc. 32; Stempin 2018a, s. 43, ryc. $7 b, 13 a)$, z podgrodzia w Santoku ${ }^{2}$ - ryc. 5c, datowany na podstawie kontekstu stratygraficznego na wiek XIII-XIV oraz z Rynku Starego Miasta w Poznaniu ${ }^{3}$ o podobnej chronologii i są bierkami wykonanymi z poroża jelenia, z klocków

\footnotetext{
${ }^{2}$ Bardzo dziękuję Pani dr Kindze Zamelskiej-Monczak z Instytutu Archeologii i Etnologii Polskiej Akademii Nauk (Oddział w Poznaniu) za udzielenie szczegółowych informacji na podstawie dokumentacji z badań.

${ }^{3}$ Dziękuję autorce badań - Pani mgr Katerinie Zisopulu-Blei kierującej działem Archeologii Miasta Poznania, Muzeum Archeologicznego w Poznaniu, za udostępnienie niepublikowanego jeszcze zabytku i udzielenie wyczerpujących informacji o okolicznościach jego odkrycia i chronologii.
} 


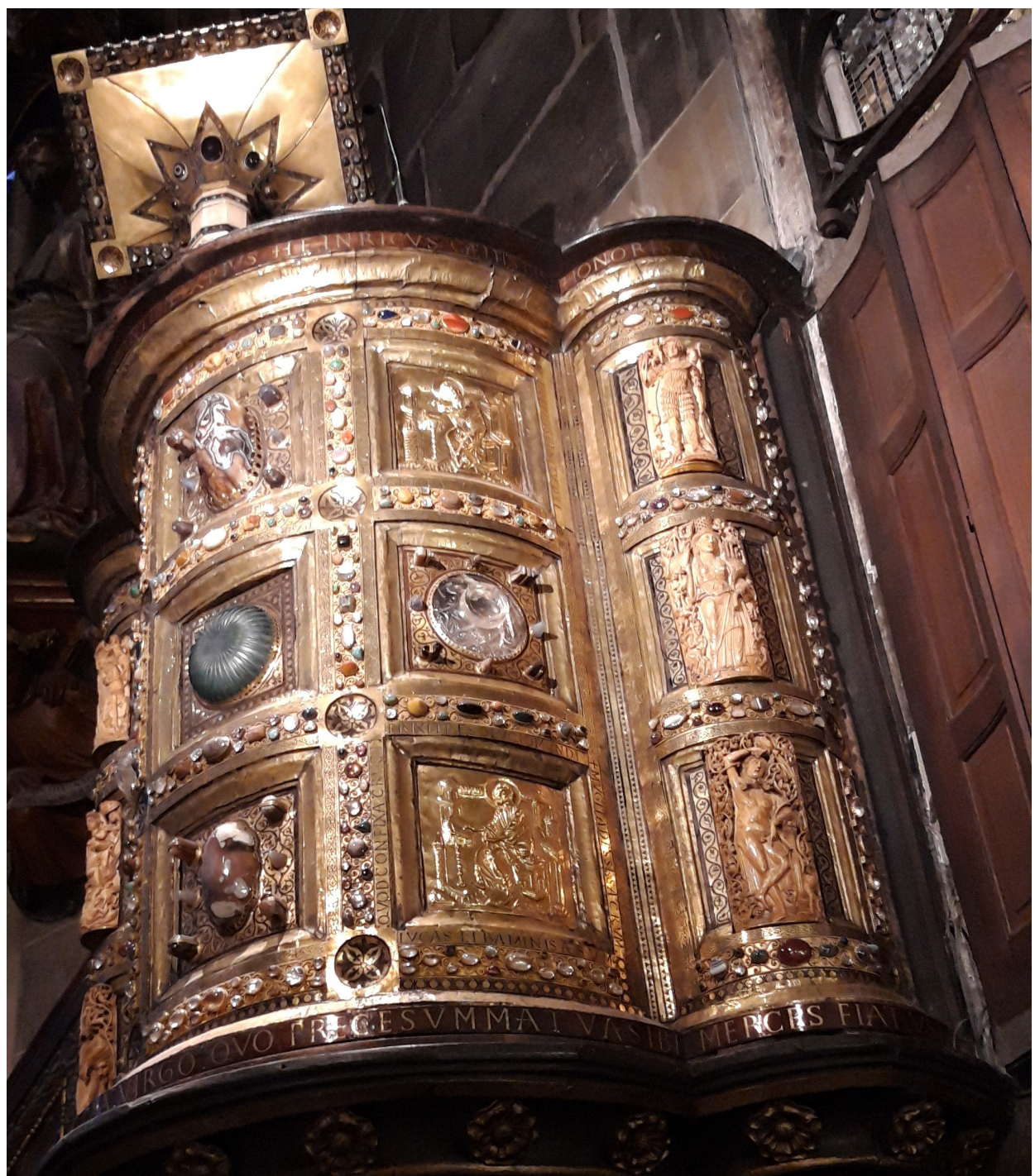

Ryc. 7. Akwizgran (około 1005-1014 r.). Ambona ufundowana przez króla Henryka II. Zdobiona kameryzacją z wykorzystaniem kompletów figur szachowych z chalcedonu i agatu (X w.). Fot. A. Stempin

o kształcie przy podstawie siedmiobocznym, bokach fasetowanych i silnie wygładzonych. Jednak bardzo prawdopodobne, że choć wywodzą się z tego samego nurtu, nie towarzyszyły już zestawowi o stylistyce arabskiej. Jednocześnie warto odnotować, że zaprezentowane w niniejszej pracy pionki fasetowane z terenu Polski są najdalej na wschód wysuniętymi przykładami tej maniery zdobniczej, niespotykanej na obszarze wschodnich rejonów Europy. Sądzę, że jest to jeden z decydujących 
argumentów wskazujących kierunek, z którego należy spodziewać się wpływów $\mathrm{i}$ inspiracji szachowych w najstarszym okresie adaptacji gry w dorzeczu Odry. Piony fasetowane, praktykowane przez całe średniowiecze, pojawiały się w zmieniających się zgodnie z nowymi trendami kompletach, będąc jednak wciąż echem najstarszych tradycji.

Kolejne zmiany w procesie recepcji szachów na gruncie europejskim dokumentują dwie figury: wieża z grodu opolskiego stanowiąca przykład maniery wzbogacania szachów stworzonych w tradycyjnym arabskim kształcie rozbudowaną dekoracją romańską. Natomiast król (bądź królowa/hetman), wykonany z poroża jelenia, ze zbiorów Muzeum Archeologicznego w Krakowie, jest dowodem doskonałej orientacji $\mathrm{w}$ trendach czerpiących inspiracje $\mathrm{z}$ ekskluzywnych kompletów z kości słoniowej, wykonywanych w rejonie śródziemnomorskim w warsztatach sycylijskich bądź północnoafrykańskich (Kluge-Pinsker 1991, s. 130, 131; Fahid 2018, s. 64-65). W trakcie badań w roku 1931 prowadzonych na Ostrówku w Opolu odkryto bardzo ciekawy przedmiot, który został wówczas skatalogowany i narysowany w inwentarzu polowym. Karta z rysunkiem i krótką notatką to obecnie jedyny ślad ${ }^{4}$, ponieważ dziś zmuszeni jesteśmy uznać interesujący nas zabytek za zaginiony (ryc. 8a). Nie mamy pewności co do surowca, z którego wykonano ten przedmiot. Opis „Verzierte Geräte aus Hirschgeweih” ulokowany pod znajdującą się obok oprawką może dotyczyć również wieży szachowej, ale nie musi. Biorąc pod uwagę wszystkie okoliczności, należy stwierdzić, że co do materiału, z jakiego ją wykonano, istnieje podejrzenie, iż była to kość słoniowa (lub równie wówczas prawdopodobny kieł morsa, ząb kaszalota lub krąg kościany wieloryba), choć nie można tego potwierdzić. Niewątpliwie nie był to wyrób miejscowy, nawet jeżeli przyjmiemy, że surowcem, z jakiego ją wykonano, było poroże, gdyż nie stwierdzono podczas badań śladów rzemiosła związanego z obróbką kości i poroża. Przedmioty wykonywane z tego surowca odkrywane na grodzisku opolskim są zdobione dość ograniczonym zestawem ornamentów, głównie linii rytych i oczek, odciskanych cyrklem, tworząc proste motywy (Hołubowicz 1956, s. 320; Norska-Gulkowa 1956, s. 52). Część wytworów obcego pochodzenia odkrytych w Opolu jest znaleziskiem, które wystąpiło pojedynczo, co sugeruje, że związane są z incydentalnym kontaktem lub aktywnością jednego użytkownika, a nie grupy regularnych odbiorców (Hołubowicz 1956, s. 331). Jeżeli jednak weźmiemy pod uwagę zespół importów odkrytych na opolskim grodzie, to można przyjąć, że należą one do pewnego zakresu dóbr ekskluzywnych, których pochodzenie jest związane ze szklakiem łączącym tereny Rusi Kijowskiej z południem Europy, na którym Opole było ważnym punktem przystankowym (Hołubowicz 1956, s. 249-251). Uznano, że w 2. połowie XII wieku mogli tu docierać kupcy italscy, czego dowodzić mogą takie znaleziska, jak perła z Zatoki Perskiej, zawieszka z muszelki

\footnotetext{
${ }^{4}$ Sfotografowana karta znajduje się w Archiwum Fotograficznym Muzeum Archeologicznego w Poznaniu.
} 


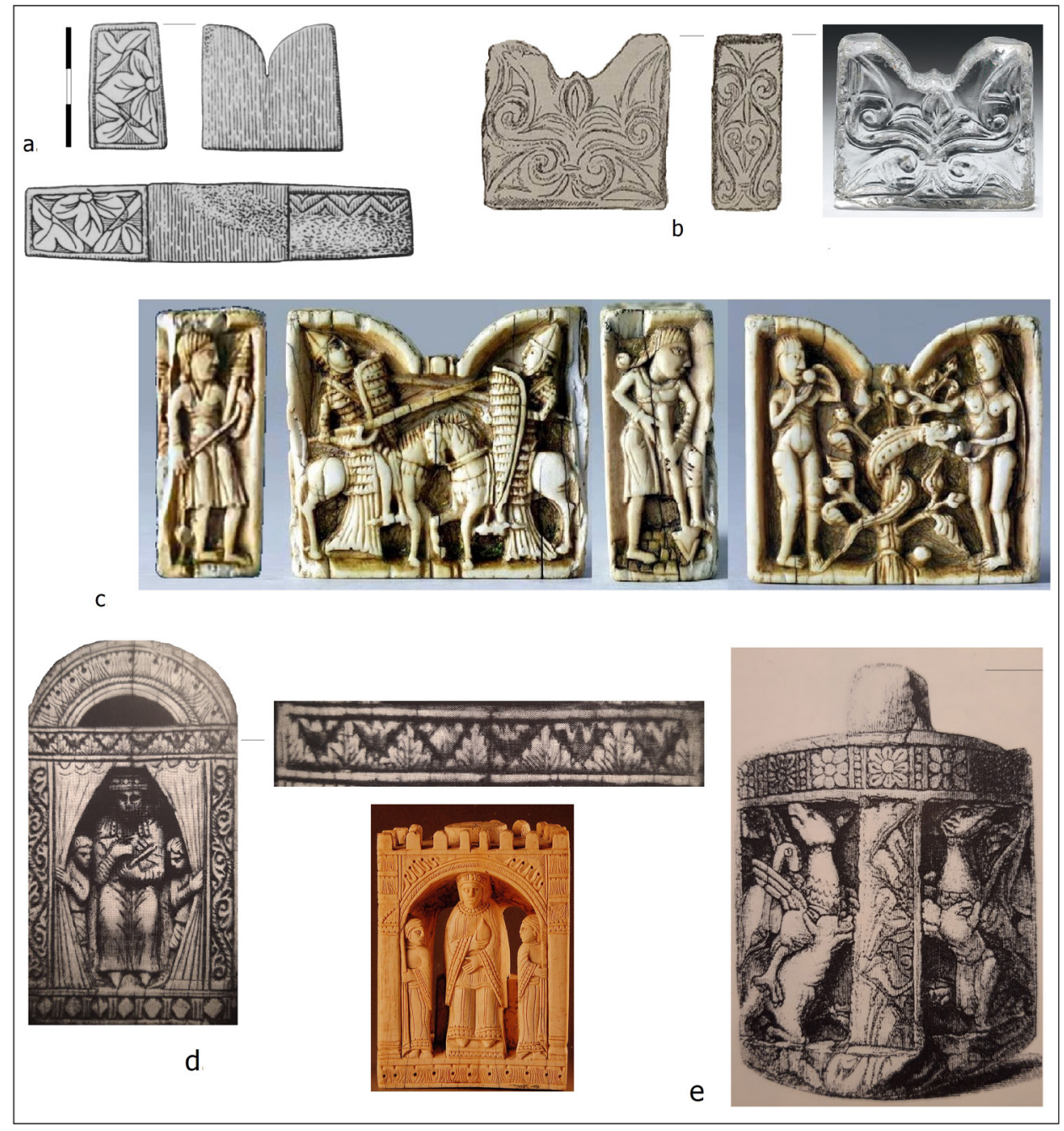

Ryc. 8. Figury szachowe, z ornamentyką romańską, X-XII w.:

a - wieża szachowa z Opola, Archiwum Muzeum Archeologicznego w Poznaniu; b - Ager, Hiszpania, wieża szachowa z kryształu górskiego w stylistyce abstrakcyjnej, dekorowana arabeską, IX-X w. (wg Fahid 2018, s. 34 ryc. 20; 171; 194); c - wieża z kości słoniowej, Bliski Wschód VIII/IX w. wtórnie rzeźbiona w XII w. na terenie Europy łacińskiej scenami z Biblii (wg Gaborit-Chopin 2003, s. Makariou 2005, s. 136, ryc. 10); d - królowe z kości słoniowej, XI w. Amalfi (Salerno), tzw. „,szachy Karola Wielkiego" z bogatą dekoracją palmetową (wg Kluge-Pinsker 1991, s. 20, ryc. 7); e - opactwo Kirstall, Anglia, XII w. kieł morsa (wg Kluge-Pinsker 1991, s. 153, ryc. 54) 
Cyprea pochodząca z Morza Śródziemnego czy kabłączek skroniowy z ptaszkiem wykonany z cyny o proweniencji hiszpańskiej. Przedmioty tego typu stanowiły towary intratnego handlu rozwijającego się na drodze z Bagdadu poprzez Syrię, Aleksandrię aż do Włoch. Prawdopodobny jest także kierunek wschodni, gdyż Kijów poprzez tereny nadczarnomorskie był odbiorcą podobnych obiektów. Odkrywane podczas badań opolskich w latach 1952-1955 tkaniny jedwabne wystąpiły w kolejnych warstwach od XI do XII wieku, co sugeruje stały ich dopływ i obecność w grodzie (Hołubowicz 1956, s. 254). Na tym tle należy rozpatrzyć również pojawienie się misy szklanej z inskrypcją arabską tłumaczoną jako ,pokój sułtanowi” (Norska-Gulkowa 1956, s. 51) oraz, jak sądzę, wieży szachowej w stylu abstrakcyjnym, z bogatą romańską warstwą ornamentacyjną. Ten ostatni zabytek jest przykładem wysokiego kunsztu rzeźbiarskiego, a przedstawiony na bocznej ściance motyw roślinny uznać należy za wyobrażenie liści akantu lub naprzemiennie układanej palmetki. Ścianki przeciwległe nie są zdobione symetrycznie - druga ma ornament geometryczny zwielokrotnionych, nakładających się na siebie trójkątów, przy czym widoczny jest tylko jego fragment, ponieważ reszta uległa najprawdopodobniej zatarciu (bądź symbol na rysunku oznacza spongiozę). Tego typu motywy pojawiają się w sztuce romańskiej dość wcześnie, ale szczególnie istotne jest $\mathrm{w}$ tym przypadku częste używanie ich do zdobienia ekskluzywnych zestawów figur szachowych. Ornament naprzemiennie układanych liści akantu (bądź palmet), jak również zbliżony do zastosowanej na opolskim egzemplarzu dekoracji geometrycznej, widnieje na figurach szachowych pochodzących z normańskiej pracowni w Amalfi nieopodal Salerno (ryc. 8d). Jest to bardzo ważny zespół figur szachowych, z punktu widzenia badań nad adaptacją gry i jej rolą w społeczeństwie średniowiecznym, ponieważ stał się on w wielu przypadkach wzorem, którego elementy odczytać można w wielu późniejszych figurach. Taka popularność ekskluzywnych zestawów związana była z ich rolą publiczną. Szachy z kryształu górskiego były oglądane w kościołach, a zestaw z Salerno wszedł w skład królewskich atrybutów poprzez włączenie go do skarbca Saint Denis. Przez długi czas ten niepełny (obecnie 16 bierek, choć jeszcze w połowie XVI wieku potwierdzono 30 sztuk) komplet szachów przypisywano własności Karola Wielkiego. Analiza uzbrojenia przedstawionych tam wojsk oraz porównanie prac warsztatu rzeźbiarskiego z Salerno z 2. połowy XI wieku jednoznacznie wskazuje na powstanie tego zespołu w pracowni południowowłoskiej (Robinson 2004, s. 4-45). Motywy ornamentacyjne stanowią jeden z wyróżników tej pracowni (palmetki-liście akantu występują tam jako dekoracje detali architektonicznych lub zdobienia tronu. Jeszcze bardziej czytelne są te same wzory na szachach z kryształu górskiego omawianych powyżej jako produkcja warsztatów bliskowschodnich lub egipskich w X-XI wieku (ryc. 8b). Zdobnictwo zbliżone do zastosowanego na wieży opolskiej znajduje się także na ekskluzywnej figurze króla z Anglii (ryc. 8e). Wszystkie te egzemplarze prezentują bardzo wysoki poziom wykonania. Forma abstrakcyjna - muzułmańska była także często wykorzystywana wtórnie, wówczas 
kształt i surowiec były traktowane jako podłoże, na którym rzeźbiono misterne wzory stylizowanej flory tzw. arabeski (Holländer 2006, s. 2; Fahid 2018, s. 34) lub tworzono rozbudowane sceny narracyjne $\mathrm{z}$ wątkami biblijnymi i literackimi (ryc. 8c). W ostatnim typie figur używano niezdobionych bierek bliskowschodnich z kości słoniowej z VIII-IX wieku, które wtórnie dekorowano w warsztatach np. paryskich (Makariou 2005, s. 136). Kopiowanie tych form na tańszych surowcach popularne było na wschodzie Europy, np. na terenie Nowogrodu, gdzie stosowano je w szachach z kości, poroża, lub nawet drewnianych (Kolczin, Janin i Jamszczikov 1985, s. 33). Łacińskie pracownie, specjalizujące się w wytwórstwie ekskluzywnych przyborów do gier z kości słoniowej, umieszczały powtarzalne zdobienia, które często stawały się ich znakiem rozpoznawczym. Przykłady takie odnajdujemy wśród wyrobów kolońskich, gdzie jednym z typów wątków ornamentacyjnych jest właśnie naprzemienna palmetka (Kluge-Pinsker 1991, s. 168: 21). Biorąc pod uwagę jakość wykonania opolskiej wieży szachowej, jej miejsca produkcji należy poszukiwać w środowisku warsztatów, w których rzemieślnicy dobrze orientowali się $\mathrm{w}$ stylistyce stosowanej $\mathrm{w}$ określonych grach i nastawieni byli na wykonywanie luksusowych bierek. Podsumowując, należy stwierdzić, że wczesnośredniowieczna wieża szachowa odkryta w Opolu jest ciekawym przykładem sztuki romańskiej i należy ją uznać za import. Być może pochodzi z obszaru południowych Włoch, na co wskazują liczne zabytki wiązane z ożywionymi kontaktami mieszkańców grodu z tymi terenami. Należy ją datować pomiędzy 2. połową XI wieku a wiekiem XII/XIII. Nie wiemy, z jakiego surowca wykonano bierkę, być może była to kość słoniowa lub materiał pokrewny.

Do europejskich nurtów stylistyki szachowej nawiązuje również figura króla lub królowej/hetmana, która znajduje się w zbiorach Muzeum Archeologicznego w Krakowie. Choć jest to znalezisko luźne i nie ma możliwości ustalenia miejsca odkrycia (Tyniec 2016, s. 74), stanowi bardzo ciekawy egzemplarz. Został on wykonany z wyjątkową starannością z poroża i prezentuje formę abstrakcyjną muzułmańską (ryc. 9e). Dekoracja oczkowa, która jest głównym motywem zdobniczym, tworzy grupy kółek wykonanych cyrklem, układanych po trzy, w regularne trójkąty. Bardzo istotny aspekt tego zdobnictwa stanowią krótkie, ale dość głębokie nacięcia, odchodzące od każdego oczka w postaci drobnych „,ząbków” czy „,pazurków”. Motyw ten powtarza się na wszystkich fragmentach zdobienia. Wokół podstawy figury wykonano trzy równoległe, opasujące ją linie ryte, przy czym pomiędzy dwiema górnymi a dolną jest niezdobiona przestrzeń. Bierka jest niewielkich rozmiarów, choć masywna, zamykająca się w kubaturze sześcianu. W symboliczny sposób przedstawia władcę siedzącego na grzbiecie słonia. Charakterystyczny jest sposób, w jaki zobrazowano fragment będący głową zwierzęcia, która od głównego korpusu bierki oddzielona została delikatną, choć wyraźną, plastyczną listwą. Podobny motyw przebiega wokół miejsca, gdzie powinien się znajdować guzek wieńczący figurę (jest on uszkodzony, stąd nie wiadomo, czy była to wyraźna kulka - jak w przypadku figur króli, czy tylko nieznaczny występ - gdy formowano 

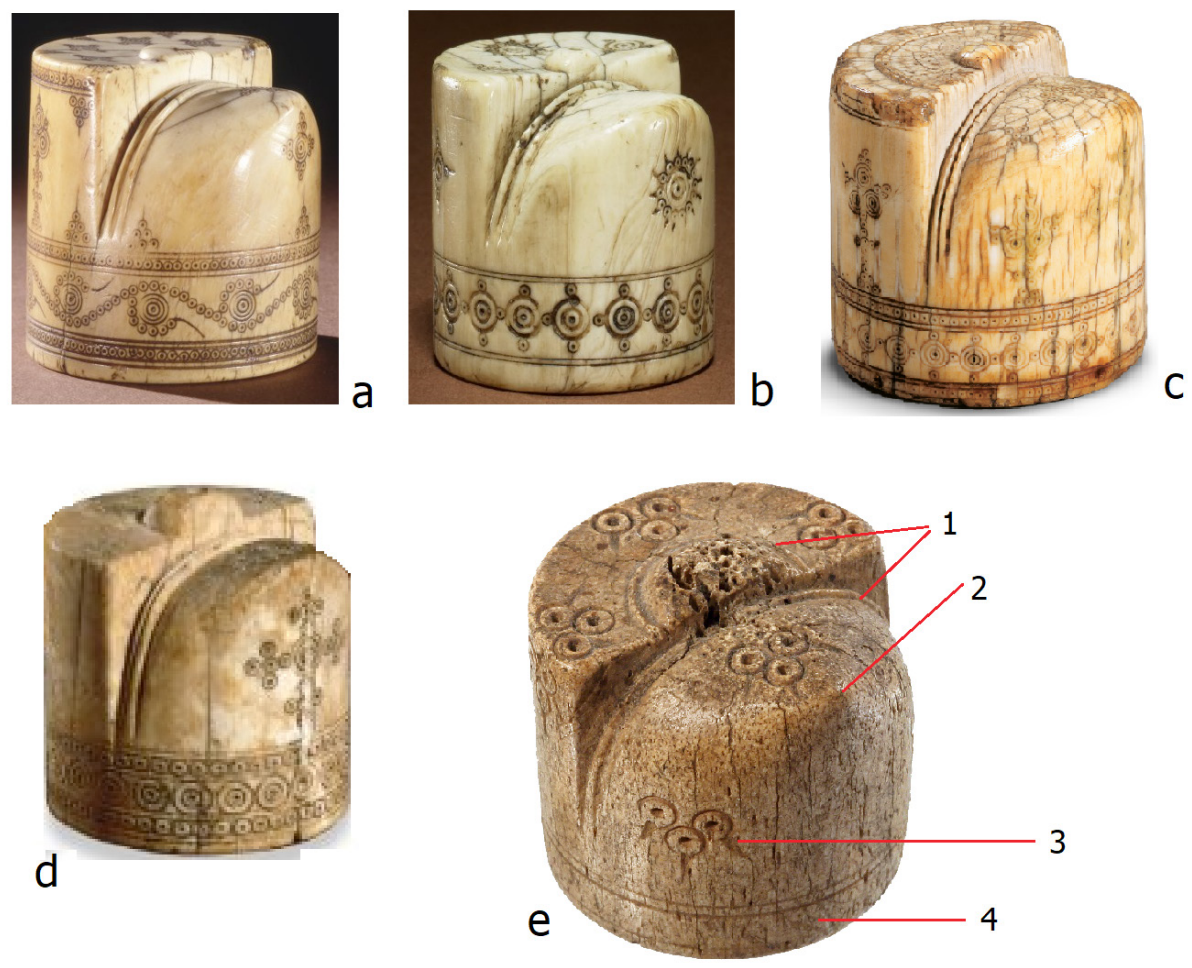

Ryc. 9. Grupa figur w stylu śródziemnomorskim (typ II b.):

a-e króle/hetmany, wykonane w konwencji abstrakcyjnej, muzułmańskiej między XI-XII w. prawdopodobnie na terenie Sycylii (względnie pd. Włoch) bądź Egiptu (a, b, d, - fot. i zbiory British Museum); c - król/hetman, kość słoniowa, XI-XII w. Zbiory: Museum für Islamische Kunst der Staatlichen Museen zu Berlin - Preußischer Kulturbesitz, fot. Ch. Krug; e - figura króla z poroża, ze zbiorów Muzeum Archeologicznego w Krakowie, fot. R. Liwoch; odnośniki: 1-4 wskazują na cechy charakterystyczne bierek wykonywanych w stylu śródziemnomorskim

królową/hetmana). Podstawowe podobieństwa do formy, a przede wszystkim do układu ornamentu, notuje się powszechnie na wielu egzemplarzach szachów wczesnośredniowiecznych, jak np. na dwóch figurach z Kijowa, datowanych na XII-XIII wiek (Sergeeva 2018, s. 135, ryc. 1.4 i 1.10), czy choćby na bierkach sandomierskich. Zbieżność ta jest jednak tylko pozorna, gdyż wydaje się, że w przypadku omawianej figury najciekawsze są cechy dotychczas nierejestrowane ani na znaleziskach odkrywanych na Rusi, ani wśród innych znajdowanych w Polsce bierek. Zaobserwowane na egzemplarzu krakowskim ${ }^{5}$ zarówno cechy morfologiczne, jak i motywy zdobnicze należą bowiem do bardzo charakterystycznych w nurcie

${ }^{5}$ „Krakowski” jest tu oczywiście określeniem umownym, ponieważ nie znamy rzeczywistego miejsca odkrycia figury, a jedynie jej zdeponowanie w Muzeum Archeologicznym w Krakowie. 
wytwarzania ekskluzywnych figur szachowych określanym mianem śródziemnomorskiego. Komplety takie produkowano w dość wąskim okresie czasu na obszarze Sycylii i południowych Włoch zajętym przez Normanów, w okresie od końca XI do XII wieku (Fahid 2018, s. 64). Powstawały w przestrzeni wielokulturowej łączącej tradycje arabskie, bizantyńskie i normańskie (ryc. 9a-d). Charakteryzują się bardzo specyficzną dekoracją powtarzalnych elementów, na które składają się:

1. Spiętrzony ornament oczkowy, wykonywany różnymi średnicami cyrkla, który w większości znanych egzemplarzy kończy się charakterystycznymi odchodzącymi od oczek ,„pazurkami” (ryc. 9e3);

2. Plastyczne listwy, jedna oddzielająca korpus figury od symbolicznego tba słonia, stosowana każdorazowo, oraz druga, zazwyczaj umieszczana na zwieńczeniu figury (ryc. 9e1);

3. Figury króli/hetmanów w tych zestawach są krępe i zamykają się w bryle sześcianu;

4. Układ ornamentu prowadzony jest według schematu: od dołu pas ograniczony dwiema liniami rytymi (najczęściej bogato wypełniony zdobieniem), następnie serie motywów oczkowych, kolejno wymodelowane listwy plastyczne, a także charakterystyczny sposób zakończenia przodu w formie ostro schodzących się boków (ryc. 9e2).

Wydaje się, że motywy te zostały zapoczątkowane w szachach produkowanych z kości słoniowej/kła morsa w rejonie Morza Śródziemnego i stały się we wspomnianym czasie wyznacznikiem stylu bardzo ekskluzywnych kompletów (Fahid 2018, s. 64-66). Trzy figury króli ze zbiorów British Museum (ryc. 9a-c) oraz król z berlińskiego Statlishe Museum (ryc. 9d) ${ }^{6}$, wykonane w zbliżonej stylistyce pochodzą prawdopodobnie $\mathrm{z}$ tych właśnie pracowni. Najbliższe dla terenów Polski analogie znajdują się w Achen (Akwizgran), gdzie odkryto trzy figury z kości słoniowej wykonane według omówionego powyżej schematu. Znajdowały się w pobliżu pałacu użytkowanego od czasu Karolingów po cały okres rządów Hohenstaufów w obrębie murów wzniesionych przez Fryderyka Barbarossę na terenie klasztoru przy kaplicy św. Mikołaja (Kluge-Pinsker 1991, s. 130-131, ryc. 31). Krótkie, trójkątne ząbki, stwarzające wrażenie „pazurków”, pojawiają się na egzemplarzach odkrywanych wyłącznie na terenie łacińskiej Europy szczególnie w miejscach związanych z obecnością normańską. Przykładem mogą być luksusowe bierki z kłów morsa odkryte na zamku Crevecceur en Auge we Francji: król/ hetman, skoczek i pionek (Grandet i Goret 2012, s. 114-116). Ale spotykane są również ich „tańsze” wersje, jak choćby goniec wykonany z poroża lub kości, czyli analogiczny do krakowskiego króla, odkryty na zamku w Northampton na

${ }^{6}$ Lokalizacja dotyczy zbiorów muzealnych, w których obecnie znajdują się figury zakupywane do kolekcji jako obiekty o szczególnych walorach ekspozycyjnych. Niestety, przez silne rozproszenie związane z ruchem kolekcjonerskim najczęściej trudno dziś ustalić miejsce ich oryginalnego pochodzenia. 
Wyspach Brytyjskich (Kluge-Pinsker 1991, s. 149). Jest to naśladownictwo ekskluzywnych wzorców wykonane zarówno w technice, jak i surowcu znacznie bardziej pospolitym, co jest często spotykaną praktyką we Francji czy Anglii. Figura króla znajdująca się w Muzeum Archeologicznym w Krakowie, uformowana z poroża, jest zapewne przykładem podobnego miejscowego naśladownictwa ekskluzywnych wzorców albo nabycia bądź otrzymania takiej tańszej wersji z ośrodków zachodnich. Należy podkreślić, że jest to jedyna w polskich zbiorach bierka królewskiej gry, posiadająca tak wyraźne odwzorowanie wczesnych figur szachowych stylu arabskiego. Kształt i ornamentyka omawianej figury świadczą o doskonałej znajomości odległych trendów, które zostały zachowane we wszystkich cechach wyróżniających, co pomimo znacznie tańszego surowca, w jakim ją wykonano, wskazuje na aspiracje do najbardziej luksusowych produktów swoich czasów. Dlatego też można $\mathrm{z}$ dużym prawdopodobieństwem datować ten egzemplarz na XI-XII wiek (Stempin 2018a, s. 42). Warto zwrócić uwagę, że pospolity materiał nie przekreśla możliwości użytkowania takiego kompletu przez ludzi zamożnych. Można wręcz wskazać pewne prawidłowości wytwórczości szachów w średniowieczu. Polegały one na produkcji kompletów ekskluzywnych z luksusowych materiałów, w wysoko wyspecjalizowanych rzadkich, ale znanych pracowniach (Bagdad, Salerno, Kolonia, Paryż), będących przedmiotem zbytku i znakiem manifestacji pozycji posiadacza - zarówno tej materialnej, jak i intelektualnej, czy też przynależności stanowej (por. Holländer 2005; Bubczyk 2009, s. 98-99, 101). Prawdopodobnie nie były to jednak komplety użytkowane na co dzień, a ich funkcję można określić jako reprezentacyjną. Pośrednio potwierdzają to najwcześniejsze zapisy testamentowe z terenów Hiszpanii. Miejsca takie, jak wspomniany już klasztor św. Idziego, wielokrotnie były obdarowywane szachami z drogocennych surowców, szczególnie z kryształu górskiego. Te same zapisy, obok ekskluzywnych bierek, wymieniają szachy z bardziej pospolitych materiałów. Jeden z takich dokumentów został sporządzony przed pielgrzymką do Composteli w 1045 roku, gdzie jej przyszły uczestnik przekazuje bratu w spadku ipsos escachos et ipsas tabulas de osso, czyli bierki kościane (Duran-Porta 2017, s. 174). Gest ten mógł mieć znaczenie sentymentalne, być może tymi szachami bracia grywali na co dzień. Struktura surowcowa zabytków szachowych z obszaru wczesnośredniowiecznej Europy wykazuje zdecydowaną przewagę bierek wykonywanych z poroża i kości, a tendencja ta zmienia się dopiero w początkach wieku XIII.

Obok najstarszych figur wykonywanych w stylistyce abstrakcyjnej muzułmańskiej, zdecydowanie dominującej w początkowym okresie rozwoju gry, już w XI wieku na terenie północnej Francji i Wysp Brytyjskich pojawiają się egzemplarze, które świadczą o rozpoczynającym się nurcie tworzenia nowych form, zmierzającym ku realistycznym przedstawieniom. Pierwsze symptomy zmian obserwuje się na bierkach, które choć w ogólnym kształcie pozostają wciąż abstrakcyjne, to ich wytwórcy łamią czystość muzułmańskiej formy i wprowadzają motywy antropomorficzne lub zoomorficzne (Kluge-Pinsker 1991, s. 139, 143, 150, 151; Holländer 
2005, s. 53; Grandet i Goret 2012, s. 61-62, 75, 103). Również te zmiany docierają do odbiorców na obszarze ziem polskich i poświadczone są kolejnym znaleziskiem z Wrocławia z 1. połowy XII wieku (Jaworski 1990, s. 42-45; Stempin 2012b, s. 81; 2018a, s. 36, 51). Skoczek szachowy odkryty tam w pobliżu domostwa nr 5 wykonany jest z poroża (ryc. 10f). Zostało tu zastosowane przedstawienie umowne, w domyśle obrazujące szyję i łeb koński, przez co należy tę bierkę zaklasyfikować jako zbieżną z nurtem arabskim - abstrakcyjnym. Nie jest to jednak czysta forma muzułmańska. Została bowiem wzbogacona o wymodelowanie cech sugerujących konkretną figurę, a więc nawiązujących do końskiej grzywy biegnącej przez całe zwieńczenie bierki. Ponadto brak tu wyodrębnionego trójkąta, zazwyczaj spotykanego w formie muzułmańskiej jako symbolu łba zwierzęcia. Ten element potraktowano inaczej, nadając kształt lekko zaokrąglony górą i kończący się ostrym, prostopadłym ścięciem. Figura wrocławska wpisuje się w nurt zmian stylistycznych zachodzących w tym samym czasie na terenie łacińskiej Europy (Jaworski 1990, s. 43-45, Grandet i Goret 2012, s. 75, 76, 103; Stempin 2012b, s. 81 ; 2018, s. 35-36). W myśl tych przemian forma abstrakcyjna zyskuje wprowadzane subtelnie elementy realistyczne, które choć nie zmieniają drastycznie kształtu figury, to jednak ją stopniowo „europeizują” i przywracają wizualny sens poszczególnym postaciom szachowym (ryc. 10). Zazwyczaj w ramach modyfikacji zaopatrzano figury w oczy, usta, modelowano realistycznie głowy, antropologizując formę w kierunku identyfikacji króla czy królowej bądź wskazania na portretowane zwierzę. Częstokroć nawet pionki otrzymują „twarze” (Grandet i Goret, 2012, s. 75). Figura skoczka/konika szachowego z Wrocławia należała zapewne do zestawu ekskluzywnego. Świadczy o tym jej doskonałe wypracowanie, w którym nie sposób pominąć elegancji i bardzo dobrze skomponowanych proporcji (Stempin 2016, s. 40). Również rozmiarem zdecydowanie odbiega od starszych pionków odkrytych w sąsiedztwie. Ponieważ jest to dość powszechny trend, rozpoczynający się w łacińskiej Europie już w XI wieku, można wskazać w tym kręgu kulturowym na liczne analogie dla wrocławskiego konika. Mamy więc do czynienia z wzorcem urealniania postaci szachowych, niemniej jednak samą formą wykonania i kształtem figura wrocławska nawiązuje do bardzo specyficznych bierek wykonywanych z gagatu na terenie Wysp Brytyjskich (Hall 2016, s. 361). I tym razem nurt zachodnioeuropejskich modyfikacji szachowych swoją wschodnią granicę osiąga właśnie na terenie Polski.

Do ciekawych egzemplarzy abstrakcyjnych należy goniec z Gniezna datowany na XII wiek (Sawicki 2016, s. 214-215, 220), który posiada rozbudowaną dekorację nie tylko w formie rytego ornamentu, ale również wprowadzonego koloru i, jak można przypuszczać, wzorowany jest podobnie jak poprzednia figura na charakterystycznych dla wytwórczości Wysp Brytyjskich figurach z gagatu (Hall 2016, s. 359-381; Stempin 2018a, s. 40-41) (ryc. 11). Bierka jest wykonana w typie arabskim z poroża. Znaleziona została na obszarze wczesnośredniowiecznej, otwartej osady podgrodowej, datowanej pomiędzy 2. połową XI a przełomem XIII/XIV wieku. 


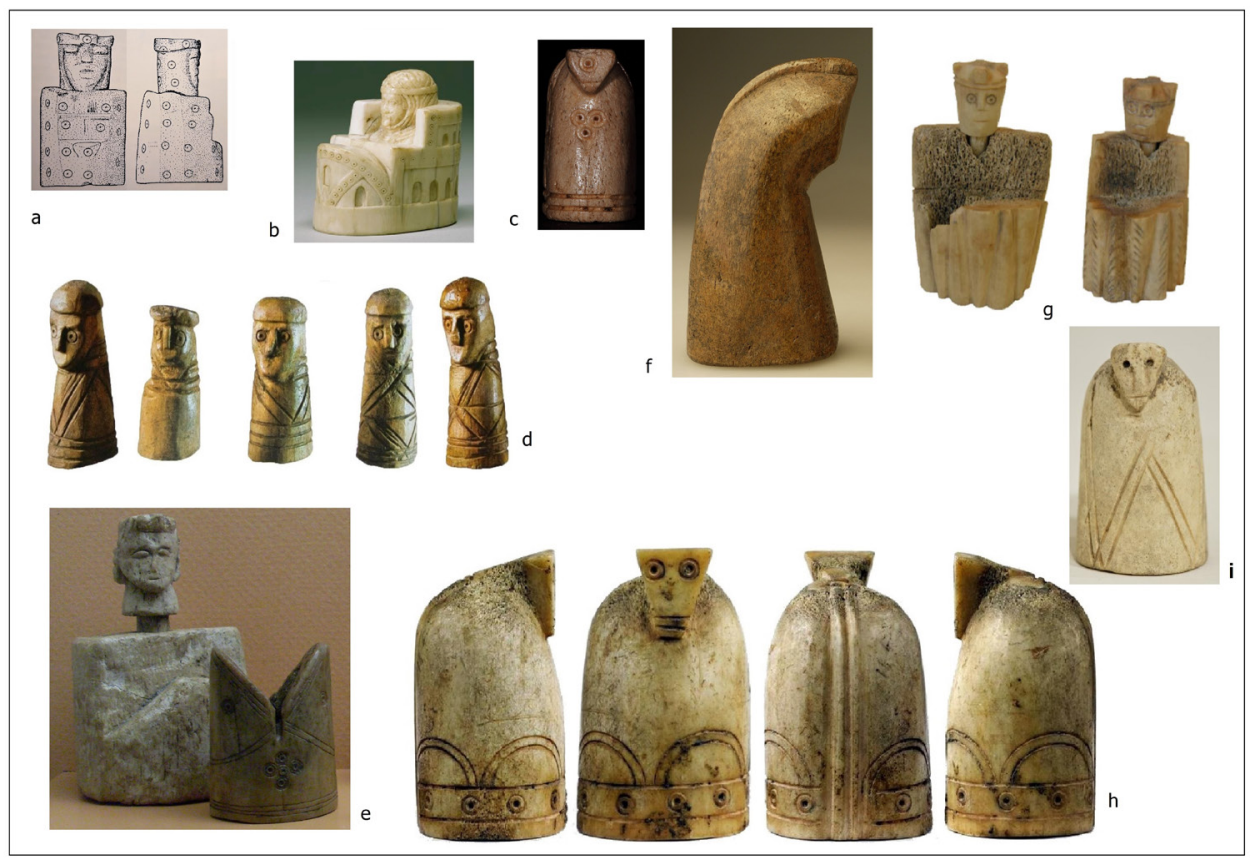

Ryc. 10. Bierki szachowe wykonane w stylistyce arabskiej z elementami antropomorficznymi i zoomorficznymi:

a - król, Harbrough, Wielka Brytania, XII/XIII w. (wg Kluge-Pinsker 1991, s. 151 ryc. A 52); b - Królowa, pd. Italia (?) wg Metropolitan Museum of Art.; c - Konik z kompletu szachów sandomierskich, fot. K. Zisopulu-Bleja; d - pionki z zamku Mayenne (Francja XI/XII w.) (wg Grandet, Goret 2012, s. 75); e - król, Schlezwig, XII w. (oraz wieża z okolic Schlezwigu - wystawa stała zamku Schlossdorf) fot. A. Stempin, f - konik z Wrocławia XII w. fot. K. Zisopulu-Bleja, g - król i królowa z Noyonne, 1. poł. XI w. (wg Goret, Talon 2009, s. 87, ryc. 7, 8); h-skoczek/koń, XI w. Chatenois, poroże jelenia, XI w. (wg Musée de Cluny-Musée National du Moyen-Âge, https://art.rmngp.fr/fr/library/artworks/ piece-d-echec-en-os-cavalier-pion_ivoire [dostęp 22.04.2019]); i - skoczek z Lucca, Włochy, kość/poroże (?), XI-XII w. (wg Cassano 2014: http://www.cciitalia.it/me/cassano.htm) (dostęp 5.08.2019)

Goniec zdeponowany był w jamie odpadkowej z XII wieku. Egzemplarz ten jest niemal identyczny jak jedna z figur skoczka w słynnym komplecie szachów sandomierskich $^{7}$ (ryc. 10c). Szachy sandomierskie, wedle najnowszych ustaleń, datować należy na 1. połowę XIII wieku (Stempin 2018b, s. 89-90), byłyby zatem nieco młodsze od gnieźnieńskiego egzemplarza i nie ma na nich śladów barwienia. Jest to istotne stwierdzenie, gdyż bierka gnieźnieńska posiada niespotykany w innych przypadkach element - ornament ryty wypełniony jest białą inkrustacją. Jej ślady widoczne są we wszystkich zagłębionych partiach zdobienia, tzn. zarówno w żłobkach, jak i oczkach. Ponadto na bocznych ściankach figury gnieźnieńskiej

${ }^{7}$ Mam tu na myśli tego skoczka, który nie był w pierwotnym zestawie, a został określony jako „dorobiony”, ,zapasowy” (Gąssowska 1964, s. 165; Stempin 2018b, s. 91). 
można zaobserwować duże płaszczyzny o wyraźnie zmienionej, czarnej barwie (poroże, z którego wykonano ten egzemplarz, jest bardzo jasne, więc ściemnienie wyraźnie się odcina od pierwotnego koloru). Bierka ta, jeżeli przyjąć, że prawdziwe jest spostrzeżenie zarówno o inkrustacji, jak i śladach barwienia ${ }^{8}$, stanowi bardzo cenny przykład zmian, jakie zachodziły w postrzeganiu kolorów w kulturze europejskiej, i wskazuje na analogie do zbliżonych bierek będących w tym samym okresie specyfiką Wysp Brytyjskich. Kwestia dotycząca barwy jest jedną z fundamentalnych w aspekcie figur szachowych. Wspominany już powyżej Einsiedeln Poem, czyli najstarszy znany dziś tekst datowany na lata 990-997 i wspominający szachy na terenie Europy, nie pozostawia wątpliwości, że pod koniec X wieku gra elit odbywała się na szachownicy o polach czerwonych i białych (Gamer 1954, s. 736). Figura barwiona na czarno kieruje uwagę na 2. połowę XII wieku, kiedy to w szachach, poza dotychczas stosowaną opozycją biało-czerwoną, pojawia się również kontrast czarno-biały. Gra wpisuje się tym samym w zapoczątkowany w tym stuleciu nurt stopniowej rehabilitacji koloru czarnego. Najczęściej przyczyna tej zmiany upatrywana jest w zwiększonym dostępie do traktatów dotyczących kolorów autorów starożytnych, wprowadzonych do dyskursu intelektualnego, dzięki intensywnie rozwijającemu się w tym stuleciu ruchowi translatorskiemu. Skutkiem tego było powszechne studiowanie na uniwersytetach wszystkich ${ }^{9}$ dzieł Arystotelesa, także tych, które były mu przypisywane, nie będąc w rzeczywistości jego autorstwa ${ }^{10}$. Na rewolucję postrzegania barw wpływ miało przede wszystkim nowe definiowanie i klasyfikacja kolorów, co skutkuje odczytaniem czarnego jako barwy ascezy i pokory, a biel i czerń stają się skrajnymi biegunami wszystkich systemów postrzegania kontrastu charakterystycznymi do dziś (Pastoureu 2006, s. 312). Badacze brytyjscy i szkoccy zwracają uwagę na inny istotny czynnik wpływający na postrzeganie barwy, widząc powód XII-wiecznych zmian w tradycji regionalnej. Kolor czarny zajmował tam na dużo wcześniej, przed szachami, szczególne miejsce wśród gier rzymskich i celtyckich, a to głównie za sprawą używanego do produkcji bierek lokalnego surowca - gagatu z Whitby (hrabstwo Yorkshire). Gagat jest odmianą węgla brunatnego, pochodzi z uwęglenia drzew z rodziny araukarii, występujących powszechnie na terenie Europy w okresie jurajskim, które uległy przemianie w środowisku beztlenowym pod ciśnieniem warstw skalnych. Występuje w odcieniach od ciemnego brązu do czerni, a w czasach antycznych nazywany był „czarnym bursztynem” (Kobielus 2012, s. 160-161; Hall

8 Jest to obserwacja makroskopowa, niemniej jednak ślady te są dobrze czytelne.

${ }^{9}$ Do czasu rozwinięcia się europejskiego ruchu translatorskiego w XII wieku, którego głównymi ośrodkami w tym czasie były: Toledo w Hiszpanii, włoski Neapol oraz dwór królów normańskich w Palermo, znane były tylko dwa dzieła logiczne Arystotelesa: Kategorie i Hermeneutyka (Przybył 2017, s. 79).

10 Traktat De coloribus, który zdobył dużą popularność w średniowieczu, nie był autorstwa Arystotelesa ani Teofrasta, jak wówczas sądzono, a jedynie któregoś z późniejszych uczniów Stagiryty, ale przyczynił się do upowszechnienia linearnej klasyfikacji kolorów (Pastoureau 2013, s. 37). 
2016, s. 361). Znajdowane na terenie Szkocji oraz północnej Anglii i Walii półkuliste czarne piony wykonane $\mathrm{z}$ gagatu użytkowane były najprawdopodobniej w grze fitchill lub hnefatafl, przy czym oba warianty są inspirowane rzymską grą ludus latrunculorum (Hall i Forsyth 2011). Przedmioty te znane są z okresu od II/III do IX wieku (hnefatfl i figury $\mathrm{z}$ gagatu w niej stosowane, kontynuowane są jeszcze długo w średniowieczu równolegle z szachami) (Lavysh 2018, s. 142, ryc. 1.5). Natomiast użytkowanie gagatu w szachach potwierdzone jest na Wyspach Brytyjskich od schyłku XI aż do XIV ${ }^{11}$ wieku. Istnieją dwa warianty wykonania bierek szachowych z gagatu: gładkie, jednolite lub inkrustowane, które mają ornament żłobiony i wypełniany: srebrem, cyną, aurypigmentem (siarczkiem) lub węglanem wapnia (Hall 2016, s. 367). W 1920 roku na terenie pierwszego na Wyspach Brytyjskich opactwa cystersów - w Rievaulx - odkryto dwie figury szachowe w stylu arabskim. Jest to król wykonany z kości wołu oraz wieża z gagatu, obie figury w stylistyce abstrakcji muzułmańskiej. Ponieważ figury wystąpiły razem, uznano za prawdopodobne, że rozróżnienie kolorystyczne zestawów osiągano właśnie poprzez dwa różne surowce, w tym wypadku rozdzielające graczy na posługującego się czarnymi kamiennymi bierkami i drugiego z jasnym zestawem kościanym (Hall 2016, s. 370). Król jest pozbawiony ornamentu, natomiast figura wieży zdobiona jest motywem oczkowym, wypełnianym srebrem (Dunning 1965, s. 53-63). Głównym źródłem gagatu w Wielkiej Brytanii jest wybrzeże i obszar śródlądowy wokół Whitby w Yorkshire. Na kontynencie znaczące złoża znajdują się w Hiszpanii w regionach Asturii, Galicji (w tym w okolicach Santiago de Compostela) i Aragonii (Rayner i Hemingway 1974). W Polsce złoża tego minerału stwierdzono w rejonie Gór Świętokrzyskich ${ }^{12}$. Nie bez znaczenia jest również fakt, że znane były szachy z gagatu wydobywanego w Azji Centralnej i datowane znacznie wcześniej niż brytyjskie. Tam wykonywane były jako zestawy opozycyjne do egzemplarzy drewnianych lub alabastrowych, a ich zdobnictwo posiada te same wątki, które spotykamy później w Europie, co wskazuje na ich znajomość w tych kręgach (Fahid 2018, s. 108-115). Goniec gnieźnieński nawiązuje stylistycznie do powyższych przykładów, jednak gagat uznawany był za minerał szlachetny i komplety z niego wykonywane musiały być kosztowne. Wybrano zatem wariant imitujący ekskluzywne szachy i zastosowano taką samą stylistykę. Podobne przykłady pochodzą z terenów Francji. Na zamku w Bressieux odkryto trzy figury szachowe (z różnych kompletów), a jedna z nich - wieża wykonana z kości - ma zdobienie w formie kółek i linii rytych. Te ostanie wypełnione są ciemną substancją, czyli jest to forma negatywowa w stosunku do egzemplarza gnieźnieńskiego (Grandet

11 Termin „gagat” występuje w publikacjach angielskojęzycznych jako jet - czasami jet-like ponieważ niewiele okazów bierek zostało zidentyfikowanych w analizach specjalistycznych. Należy przyjąć, że część z nich może być wykonana z surowców traktowanych jako substytuty rzeczywistego gagatu, a więc $z$ hematytu, łupków bitumicznych lub węgla brunatnego. Posiadają one również czarną (lub zbliżoną do czarnej) barwę (Hall 2016, s. 360).

12 Rezerwat Gagaty Sołtykowskie. 

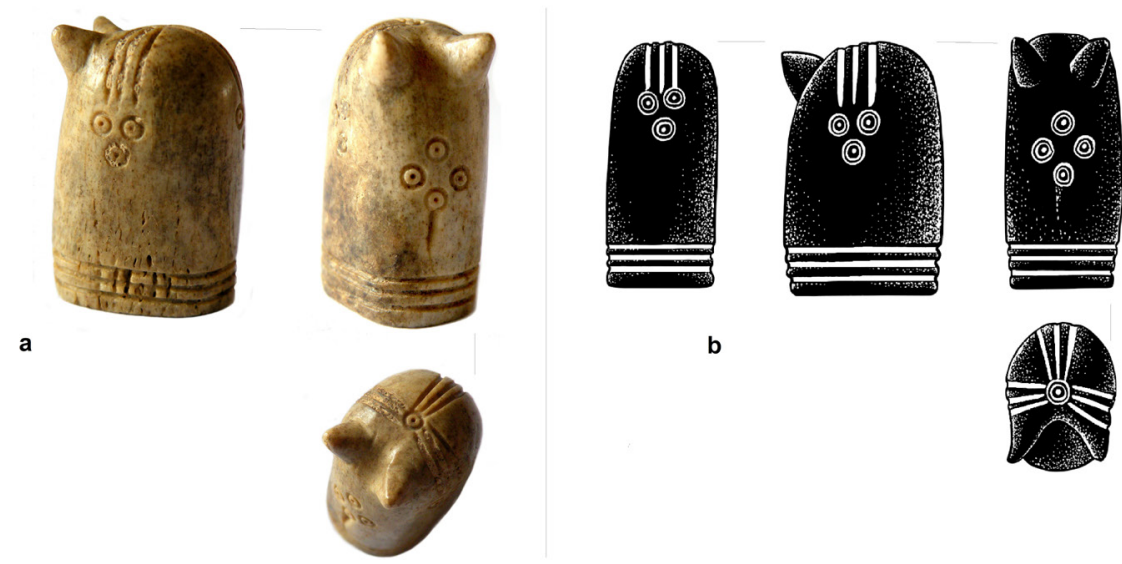

b

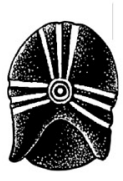

Ryc. 11. Figura gońca z Gniezna oraz wizualizacja pierwotnego, prawdopodobnego jej wyglądu: a - fot. T. Sawicki, b - opr. A. Stempin, rys. J. Kurkowicz

i Goret 2012, s. 94, 95). Na obszarze wschodniej Europy również spotykane są podobne rozwiązania (Medvedeva 2018, s. 120, ryc. 3.3). Do barwienia figur z kości i poroża używano głównie roślin, i tak uzyskanie barwy czarnej możliwe było dzięki wyciągom z liści mącznicy lekarskiej, a także kory drzew: olchy, dębu, czeremchy, kruszyny oraz liści sumaka. Istotną rolę w procesie barwierskim odgrywały utrwalacze. Stosowano tzw. zaprawy: ałun, ług sodowy, kwas chlebowy, serwatkę, kwas wykonany z ciepłej wody z mąką, korę dębu, galasówkę, liście sumaka, kawałki zardzewiałego żelaza oraz mocz (Schmidt-Przeworska 2009, s. 17).

$\mathrm{Na}$ koniec warto jeszcze odnieść się do powszechnej formy ornamentacyjnej, która często w przypadku figur szachowych wskazywana jest jako „lokalna”. Okazuje się jednak, że ornament w formie motywów łączących linie ryte i kółka jest jednym z bardziej charakterystycznych wśród figur szachowych i dotyczy to zarówno terenów łacińskiej Europy, jak i wschodniej (Linder 1975, s. 78; Kluge-Pinsker 1991; Chapman 2005, s. 3, ryc. 2; Grandet i Goret 2012; Sergeeva 2018, s. 133-140). Jest to niewątpliwie konsekwencja znajomości okazów, jakie docierały z południa, z terenów bliskowschodnich. Na obszarze wschodnioirańskim, szczególnie w rejonie Nishapur, będącym w VIII-XI wieku jednym z najważniejszych centrów rozwoju i produkcji szachów, motywy takie stały się dominującą formą zdobnictwa (Fahid 2018, s. 59, 88-89). Występowała tam również dość duża różnorodność surowcowa - od ekskluzywnych, jak kość słoniowa czy jadeit - po drewno (Fahid 2018 s. 104-105, 213-214). Można wskazać niemal identyczny układ kombinacji linii rytych i różnorodnych odcisków kółek, wykonywanych cyrklem na bliskowschodnich pierwowzorach figur szachowych z kości słoniowej. Zwraca się uwagę na fakt, że motywy te były uznawane za ważne i nie rezygnowano $\mathrm{z}$ nich nawet wtedy, kiedy surowiec zmieniano na twardszy. Powielanie 
bowiem w tym samym rejonie w X-XI wieku wzorów zawierających odciski kółek W materiale takim jak jadeit wymagało dużo większych nakładów pracy (Fahid 2018, s. 213-214). Wraz z ekspansją arabską, a także szerokimi kontaktami ze światem muzułmańskim, wzorce te zaczęły docierać z południa na teren Europy. Bierki ornamentowane analogicznymi zestawami motywów po raz pierwszy pojawiają się w łacińskiej Europie na przełomie XI/XII wieku w pracowniach sycylijskich, gdzie w tzw. nurcie śródziemnomorskim twórczo zaadoptowano zarówno formę abstrakcyjną, jak i motywy zdobnicze. Od tego czasu kombinacje linii rytych i kółek odnajdujemy na szachach w stylistyce abstrakcyjnej muzułmańskiej, w różnych wariantach i odmianach często lokalnie modyfikowanych. Na terenie wschodniej Europy częściej spotyka się wyłącznie odciski cyrkla, natomiast w łacińskiej Europie łączenie tych dwóch elementów było bardziej powszechne.

Zaprezentowane tu pokrótce bierki szachowe wykonane w stylistyce abstrakcyjnej muzułmańskiej dowodzą, że wśród odkrytych na terenie Polski zabytków, wiązanych z szachami, znalazły się przykłady większości nurtów i przemian, którym gra podlegała od początku pojawienia się na kontynencie europejskim, łącznie ze znajomością różnych jej wariantów i fluktuacji. Są wśród nich zarówno egzemplarze wykonane z surowców ekskluzywnych, jak i takie, które zwykliśmy uznawać za pospolite. W powyższych rozważaniach nie uwzględniono najbardziej spektakularnych zabytków łączonych z grą w szachy, jakie odkryto na terenie Polski szachów sandomierskich. Komplet średniowiecznych bierek szachowych jest odkryciem niecodziennym. Szachy sandomierskie należą do wąskiego grona takich przypadków, wśród których najbardziej znany jest zespół 93 figur wykonanych głównie z kłów morsa, znaleziony w 1831 roku na szkockiej wyspie Lewis (Caldwell i Hall 2014; 2018). Poza tym przykładem, równie cennym źródłem są szachy z włoskich stanowisk skupionych w okolicach Rzymu, jak np. Venafro (Elia 1939, s. 59) czy francuskich zamków Noyonne (Goret, Talon i Yvinec 2009, s. 89) i Mayenne (Grandet i Goret 2012). W skarbcach katedralnych Saint Denis (Grandet i Goret 2012, s. 144-145) czy Osnabrück (Kluge-Pinsker 1991; Fahid 2018, s. 317) przechowywane są kosztowne, bardzo bogato ornamentowane i będące dziełami sztuki rzeźbiarskiej, zestawy z kości słoniowej i kryształu górskiego. W tym zacnym gronie równorzędne miejsce zajmuje komplet niepozornych, drobnych figurek, które bez większych przeszkód można zmieścić w dłoniach, a których pojawienie się przeszło pół wieku temu na Wzgórzu św. Jakuba w Sandomierzu było tak zaskakujące. Jednak jak wykazały ostanie badania tych przedmiotów, ich datowanie jest młodsze w stosunku do wskazywanego we wcześniejszej literaturze, pochodzą z 1. połowy XIII wieku (Stempin 2018b, s. 68-93; Stempin 2021, a zatem nie należą do zakresu chronologicznego omawianego w niniejszym opracowaniu ${ }^{13}$.

13 Planowane jest w najbliższym czasie poświęcenie szachom sandomierskim osobnej monografii, będącej efektem pracy doktorskiej napisanej przez autorkę artykułu pod kierunkiem prof. dr. hab. Andrzeja Buko w Instytucie Archeologii i Etnologii PAN. 
Wszystkie z wymienionych powyżej bierek, należących do najstarszego horyzontu adaptacji gry na terenie Polski, prezentują wysoki poziom wykonania, a co najważniejsze doskonałą orientację ich producentów w wiodących na terenie łacińskiej Europy trendach stylistycznych. Pojawiają się też na tych ziemiach w czasie zbieżnym z analogicznymi formami na obszarach ościennych. Przykłady powyższe potwierdzają atrakcyjność formy arabskiej, która polegała niewątpliwie na prostocie geometrycznych kształtów, sprzyjających łatwości ich odróżniania przez graczy (również przez uczących się gry), ale też nie stwarzała większych kłopotów wykonawcom-rzemieślnikom. Forma arabska abstrakcyjna przyczyniła się z pewnością do szybkiego rozprzestrzeniania znajomości gry, o czym świadczą również znaleziska $\mathrm{z}$ rodzimych zbiorów.

\section{BIBLIOGRAFIA}

Adamczyk P. 2012, Gry planszowe - tabula, w: A. Stempin (red.), Magia gry, sztuka rywalizacji, Poznań, s. 41-49.

Banaszkiewicz J. 1999, Rodulf, król Herulów, który grat (Paweł Diakon, Hist. Long., I, 20), w: M. Drzewiecki (red.), E scientia et amicitia. Studia poświęcone profesorowi Edwardowi Potkowskiemu w sześćdziesięciopięciolecie urodzin i czterdziestolecie pracy naukowej, Warszawa-Pułtusk.

Batey C., Clarke H. 1998, Wikingowie, Warszawa.

Bubczyk R. 2003, Gry w szachy i kości w średniowiecznej Polsce, jako element europejskiej kultury rycerskiej. Rocznik Polskiego Towarzystwa Heraldycznego nowej serii, t. 6 (17), s. 9. Warszawa.

- 2003a, Gry w szachy i kości jako rozrywki duchowieństwa w średniowiecznej Polsce, Annales Universitatis Mariae Curie-Skłodowska, Sectio F, 58, Lublin, s. 25-33.

- 2005, Szachy i rycerze, Lublin.

- 2009, Gry na szachownicy w kulturze dworskiej i rycerskiej średniowiecznej Anglii na tle europejskim, Lublin.

- 2010, Rex ludens ad tabulam - gry na szachownicy a rzeczywistość, w: K. Skupieński (red.), Średniowiecze w rozjaśnianiu, Warszawa, s. 51-61.

Buriakow Yu, F. 1980, K datirovke i atributsii nekatorykh shakhmatnykh naborov (v svete nakhodok $1977 \mathrm{~g}$. na Afrasiabe), „Sovetskaya Arkheologiya”, t. 3, s. 162-172.

Caldwell D., Hall M. (red.) 2014, The Lewis Chessmen. New Perspectives, Edynburg.

- 2018, The Hoard of Gaming Pieces from Lewis, Scotland: context and meaning, w: A. Stempin (red.), The Cultural Role of Chess in Medieval and Modern Times 50th Anniversary Jubilee of the Sandomierz Chess Discovery. Bibliotheca Fontes Archaeologici Posnaniemses, t. 21, s. 97-108.

Caldwell D., Hall M., Wilkinson M. 2009, The Lewis Hoard of Gaming Pieces: A Re-examination of their Context, Meanings, Discovery and Manufacture, "Medieval Archaeology", t. 53, s. 155-204.

- 2013, The Lewis Hoard of Gaming Pieces: A Re-examination of their Context, Meanings, Discovery and Manufacture, Edynburg.

Cazaux J.L. 2012, Les jeux d'échecs du moyen âge. Ou la quête du jeu parfait. Histoire et Images Médiévales, t. 28, s. 56-63.

Chapman A. 2000, A stylised chess piece from the moated enclosure at Tempsford, "South Midlands Archaeology", t. 30, s. 7-8.

Contadini A. 1995, Islamic Ivory Chess Pieces, Draughtsmen and Dice, w: Islamic Art in the Ashmolean Museum, s. 111-155, Oxford.

Cordez P. 2007/2008 (2011), Images ludiques et politique féodale. Les matériels d'échecs dans les églises du XIe siècle, "Ludica", t. 13-14, s. 115-136.

Duczko W. 2006, Ruś Wikingów, Warszawa. 
Dunning G.C. 1965, Heraldic and decorated metalwork and other finds from Rievaulx Abbey, Yorkshire, "Antiquaries Journal", t. 45, s. 53-63.

Duran-Porta J. 2017, Nuevos datos sobre la temprana difusión del ajedrez en los Pirineos, y una reflexión sobre las piezas de Àger, w: Espatio, Tiempo Y Forma, Serie VII Historia del Arte Revista de la Facultad de Geografía e Historia, t. 5, s. 171-187.

Eales R. 2001, Chess, The History of a Game, Glasgow.

Eder M. 1994, Die Schachfiguren aus Afrasiab: Fragen an die Wissenschaft zur Deutung, Zeitstellung und Ikonographie, "Antike Welt", t. 25(1), s. 71-78.

Elia O. 1939, Un gioco di scacchi de eta romana, "Bullettino del Museo dell'Impero Romano", t. 67, s. 57-63.

Fahid D.F. 2018, Chess and other games pieces from islamic lands, London.

Fajardo-Acosta F. 2015, The King is Dead, Long Live the Game: Alfonso X, el Sabio, and the Libro de açedrex, dados e tablas, "eHumanista", t. 31, s. 489-523.

Gamer H.M. 1954, The Earliest Evidence of Chess in Western Literature: "The Einsiedeln Verses", "Speculum", vol. 29 (4), s. 734-750.

Gąssowska E. 1964, Wczesnośredniowieczne szachy z Sandomierza, „Archeologia Polski”, t. 9, s. 148-169.

Golladay S.M. 2007, Los Libros de Acedrex Dados e Tablas: Historical, Artistic and Metaphysical Dimensions of Alfonso X's Book of Games, Arizona.

Giżycki J. 1984, Z szachami przez wieki i kraje, Warszawa.

Goldschmidt A. 1926, Die Eifenbeinskulpturen an der romanischen Zeit, IV.7, Berlin.

Goret J.F, Talon M., Yvinec J.H. 2009, Le jeu d'échecs de Noyon dans son contexte archéoLogique et historique, w: Revue Archeologique de Picardie, s. 79-119.

Grandet M., Goret J.F. 2012, Echecs et Trictrac, Fabrication et usages des jeux de tables au moyen age, Paris.

Hall M.A. 2011, Playtime Everyday: The Material Culture of Medieval Gaming, w: A History of everyday life in Medieval Scotland 1000 to1600, Edynburg, s. 145-168.

- 2016, Playing the dark side: a look at some chess and other playing pieces of jet and jet like materials from Britain, w: F. Hunter, A. Sheridan (red.),Ancient Lives. Object, People And Place In Early Scotland. Essays For David V Clarke On His 70th Birthday, s. 359-381, Edynburg.

Hall M.A., Forsyth K. 2011, Roman rules? The introduction of board games to Britain and Ireland, "Antiquity", t. 85 (330), s. 1325-38.

Hensel W., Pazdur J. (red.), 1978, Historia kultury materialnej Polski 1: od VII do XII wieku. M. Dembińska i Z. Podwińska (red.), Wrocław-Warszawa-Kraków-Gdańsk

Hojdis B. 2000, O wspótistnieniu stów i obrazów w kulturze polskiego średniowiecza, Gniezno-Poznan.

Holländer B. i H. 2006, Das Spiel des Schach. Ein Spiel aus dem Osten. Eine Ausstellung vom 20. Mai-25. Juni 2006 anlässlicgdes Kongresses der Chess Collectors international (CCI) in Berlin im Museum für Islamische Kunst, Staatliche Museen zu Berlin, Pergamonmuseum, Berlin.

Hołubowicz W. 1956, Opole w wiekach X-XII, Katowice.

Iwańczak W. 2001, Jak grano w szachy w średniowiecznych Czechach, w: W. Iwańczak; S. Kuczyński (red.), Ludzie, kościól, wierzenia. Studia z dziejów kultury i spoleczeństwa Europy Środkowej, Warszawa, s. 454-455.

Karłowska-Kamzowa A. 2000, Społeczeństwo średniowieczne na szachownicy życia. Jakuba de Cessolis Traktat o powinnościach o obyczajach szlachty na podstawie gry w szachy. Fragmenty w thumaczeniu polskim T. Jurek, E. Skibiński, Poznań.

Kluge-Pinsker A. 1991, Die Salier. Schachspiel und Trictrac. Zeugnisse mittelalterlicher Spielfreunde aus salischer Zeit, Sigmaringen.

Kobielus S. 2012, Lapidarium christianum, Kraków.

Kolczin B.A., Janin V.L., Jamszczikov S.V. 1985, Drevnij Novgorod. Prokładno isskustvo i archeołogija, Moskwa.

Linder I.M. 1975, Szachmaty na Rusi, Moskwa.

Lavysh K. 2018, A vizier from Lukoml and a pawn from Volkovysk: on imported and locally manufactured products among the finds of figurative chessmen in Rus, w: A. Stempin (red.), The Cultural Role of Chess in Medieval and Modern Times 50th Anniversary Jubilee of the Sandomierz Chess Discovery, Bibliotheca Fontes Archaeologici Posnaniemses, t. 21, s. 141-147, Poznań. 
Murray H.J.R. 1913, A History of Chess, Oxford.

Medvedeva O. 2018, The Spread of Chess in Medieval Belarus, w: A. Stempin (red.) The Cultural Role of Chess in Medieval and Modern Times 50th Anniversary Jubilee of the Sandomierz Chess Discovery, Bibliotheca Fontes Archaeologici Posnaniemses, t. 21, s. 113-131, Poznań.

Makariou S. 2005, Le jeu d'échecs, une pratique de l'aristocratie entre islam et chrétienté des IX-XIII siécles, "Les Cahiers de Saint-Michel de Cuxa", t. 36, s. 127-139.

Norska-Gulkowa M. 1956, Sztuka wczesnośredniowiecznego Opola, „Kwartalnik Opolski”, t. 2, s. 40-62. Pastoureau M. 2006, Średniowieczna gra symboli, Warszawa.

- 2013, Niebieski. Historia koloru, Warszawa.

Przybył M. 2017, Arystoteles taciński, w: A. Stempin (red.), Spacery z Arystotelesem, s. 77-87, Poznań. Rayner D.H., Hemingway J.E. 1974, The Geology and Mineral Resources of Yorkshire, Leeds.

Rundkvit M., Williams H. 2008, A Viking Boat with Amber Gaming Pieces Excavated at Skamby, Östergötland, Sweden, "Medieval Archaeology", t. 52, s. 69-101.

Riddler I. 1995, Anglo-Norman Chess, w: De Voogt A.J. (red.), New Approaches to Board Games Research: Asian Origins and Future Perspectives, International Institute for Asian Studies, Leiden, s. 99-110.

Robinson J. 2004, The Lewis Chessmen, London.

Rulewicz M. 1961, Wczesnośredniowieczne gry w ośrodkach miejskich na Pomorzu, „Z otchłani wieków", t. 27, s. 1: 19-25.

Sawicki T. 2016, Średniowieczne i nowożytne przybory do gier z Gniezna, „Rocznik Muzeum Początków Państwa Polskiego w Gnieźnie", t. 2, s. 170-236.

Schädler U. 2008, Eine Bergkristall-Schachfigur in der Schweiz, w: S. Schönle (red.), Festschrift Egbert Meissenburg, s. 654-667, Wiedeń.

Schulte M. 2017, Board games of the Vikings - From hnefataft to chess, "Maal og Minne" 2 (2017), s. $1-42$.

Schmidt-Przeworska K. 2009, Barwienie metodami naturalnymi, Zawady.

Sergeeva M. 2018, Old Rus chess pieces of bone and antler from Kyiv and the Kyiv region, w: A. Stempin (red.), The Cultural Role of Chess in Medieval and Modern Times 50th Anniversary Jubilee of the Sandomierz Chess Discovery, Bibliotheca Fontes Archaeologici Posnaniemses, t. 21, s. 132-140, Poznań.

Schädler U., Calvo R. 2009, Alfons X. "der Weise”: Das Buch der Spiele, Salzburg-La Tour de Pailz.

Słupecki L. P. 1998, Wyrocznie i wróżby pogańskich Skandynawów, Warszawa.

Stempin A. 2008, Czy we wczesnym średniowieczu, na południowym wybrzeżu Battyku grano w szachy?, w: M. Bogacki, M. Franz, Z. Pilarczyk (red.), Kultura Ludów Morza Bałtyckiego. Starożytność $i$ średniowiecze. Mare Integrans. Studia nad dziejami wybrzeży Morza Baltyckiego, s. 195-209, Toruń.

- 2012a, Astragalusy - czyli dlaczego gramy sześciennymi kostkami?, w: A. Stempin (red.), Magia gry sztuka rywalizacji, s. 5-19, Poznań.

- 2012b, Szachy geneza gry i europejskie poczatki, w: A. Stempin (red.), Magia gry, sztuka rywalizacji, s. 72-87, Poznań.

- 2018a, An archaeology of chess pieces from medieval Poland: problems and possibilities, w: A. Stempin (red.), The Cultural Role of Chess in Medieval and Modern Times. The jubilee of the 50th anniversary of the discovery of the Sandomierz chess, Bibliotheca Fontes Archeologici Posnanienses, t. 21, s. 61-73, Poznań.

- 2018b, Sandomierz Chessmen Revisited, w: The Cultural Role of Chess in Medieval and Modern Times. 50th Anniversary Jubilee of the Sandomierz Chess Discovery, A. Stempin (red.), Bibliotheca Fontes Archaeologici Posnanienses, t. 21, s. 81-93, Poznań.

- 2019, Szachy jako gra i metafora cywilizacji europejskiej, w: A. Stempin (red.), Geniusz Europy, Poznań.

Strzelczyk J. 2010, Apostołowie Europy, Poznań.

Tabor D., 2016, Kolekcje chrześcijaństwa w średniowieczu - próba odczytania znaczenia na podstawie wybranych przyktadów, „Polonia Sacra” 20 (2016), nr 4(45), s. 177-202.

Toussaint G. 2012, Cosmopolitan Claims: Islamicate Spolia During the Reign of King Henry II, 1002-1024, "The Medieval History Journal”, t. 15, 2 (2012), s. 299-318. 
Tyniec A. (red.) 2016, Chrzest 966. Oblicza chrystianizacji, Kraków.

Wąs A. 2008, Aikoniczny obraz Boga w islamie, ,Arteria. Rocznik Katedry Sztuki Wydziału Nauczycielskiego Politechniki Radomskiej", t. 6, s. 7-13, Radom.

Wiesiołowski J. 1993, Hołub z Bordeaux herbu Wczele, „Rocznik Polskiego Towarzystwa Heraldycznego" 1(12), s. 13-23.

Yalom M. 2005, Birth of the Chess Queen, New York. 